University of Rhode Island

DigitalCommons@URI

2015

Stakeholder Perceptions of Seaport Resilience Strategies: A Case Study of Gulfport (Mississippi) and Providence (Rhode Island)

\author{
Austin Becker \\ University of Rhode Island, abecker@uri.edu \\ Margaret R. Caldwell
}

Follow this and additional works at: https://digitalcommons.uri.edu/maf_facpubs

The University of Rhode Island Faculty have made this article openly available.

Please let us know how Open Access to this research benefits you.

This is a pre-publication author manuscript of the final, published article.

Terms of Use

This article is made available under the terms and conditions applicable towards Open Access

Policy Articles, as set forth in our Terms of Use.

Citation/Publisher Attribution

Becker, A. \& Caldwell, M. R. (2015). Stakeholder Perceptions of Seaport Resilience Strategies: A Case

Study of Gulfport (Mississippi) and Providence (Rhode Island). Coastal Management, 43(1): 1-34.

Available at: http://www.dx.doi.org/10.1080/08920753.2014.983422

This Article is brought to you for free and open access by the Marine Affairs at DigitalCommons@URI. It has been accepted for inclusion in Marine Affairs Faculty Publications by an authorized administrator of DigitalCommons@URI. For more information, please contact digitalcommons-group@uri.edu. 


\title{
STAKEHOLDER PERCEPTIONS OF SEAPORT RESILIENCE STRATEGIES: A CASE STUDY OF GULFPORT (MISSISSIPPI, USA) AND PROVIDENCE (RHODE ISLAND, USA)
}

\begin{abstract}
Climate change is having and will continue to have a range of negative impacts on socialenvironmental systems. Many ports, with their coastal locations and essential roles in regional and national economies, face particular exposure to storm impacts that may worsen with climate change. Currently in the U.S., port resilience planning falls primarily upon port operators. Engaging a wider range of stakeholders in long-term seaport functioning may reduce risks from disruptive and potentially irreversible impacts of climate change. This study uses empirical data gathered through two case studies of highly exposed U.S. ports, Gulfport (MS) and Providence (RI), to identify strategies that port planners and external stakeholders consider feasible for enhancing their port's resilience. This paper categorizes these resilience strategies and suggests the potential role that different stakeholders could play in facilitation and implementation.
\end{abstract}

Short title: Stakeholder Perceptions of Seaport Resilience Strategies

Key words: Resilience, Stakeholders, Seaports, Climate Adaptation, Natural disasters, Port resilience, Strategies, Risk Reduction

Authors:

Correspondence to:

Austin Becker, PhD

Assistant Professor of Coastal Planning, Policy, and Design

Departments of Marine Affairs and Landscape Architecture

College of the Environment and Life Sciences, University of Rhode Island

1 Greenhouse Road, Suite 205 | Kingston, RI 02881

e: abecker@uri.edu | p: 401-874-4192

Margaret R. Caldwell, JD

Executive Director, Center for Ocean Solutions

Director, Environmental and Natural Resources Law \& Policy Program at Stanford Law School, 473 Via Ortega, Room 193

Stanford, CA 94305

Phone: 650-725-9475

Fax: 650-721-2957

Please cite as: Becker, A., Caldwell, M., (In press), "Stakeholder Perceptions Of Seaport Resilience Strategies: A Case Study of Gulfport (Mississippi, USA) and Providence (Rhode island, USA)." Journal of Coastal Management.

Acknowledgements: The authors wish to thank Prof. Pamela Matson, Prof. Martin Fischer, Dr. Susi Moser, Dr. Mike Mastrandrea, Suejung Shin, Ernestine $\mathrm{Fu}$, and the 57 interviewees who graciously provided their time and expertise for this research. 


\section{INTRODUCTION}

A growing body of research indicates that climate change will continue to have a range of negative impacts on social-environmental systems, including an increasing risk to storm impacts in coastal areas (USDOT 2013, Hallegatte et al. 2013, Grinsted, Moore, and Jevrejeva 2013). Consequently, researchers and practitioners are exploring how to reduce vulnerability and increase resilience of these systems. Evidence suggests that adaptation efforts benefit from stakeholder engagement and participation (Wilbanks and Kates 1999, Eakin and Luers 2006, Cone et al. 2013) on a scale that is aligned with the scale at which management occurs (Cash and Moser 2000). A foundational step in the process of adaptation identifies and assesses resilience strategies that address the needs of a range of stakeholders (Moser and Ekstrom 2010), but little work has been done in this area with stakeholders of specific pieces of coastal infrastructure such as seaports (e.g., port operators, port tenants, and representatives from the public policy sector, academia, and community groups) (EPA 2008, Becker et al. 2013).

Seaports facilitate the exchange of goods and benefit regional and national economies and social systems. Ports serve many different stakeholders, and contribute to diverse goals that include: providing economic benefits, environmental protection, improving quality of life, reducing tax burdens, facilitating trade, and more (Winkelmans 2007). As a result, natural disasters at ports affect stakeholders directly and indirectly (Becker et al. 2014). Port operators typically assume responsibility for long-term disaster and resilience planning, but short-term economic profits, and for some ports, economic development, normally drive port planning (Memos 2004, Dooms and Verbeke 2006).

In the research reported here, we explore ways that port planners and external stakeholders perceive strategies for resilience building and suggest ways they can share responsibility for implementation. Through case studies of two highly exposed ports in the U.S., Providence (Rhode Island) and Gulfport (Mississippi), this paper identifies stakeholders' perceptions of potential strategies to reduce port vulnerability to impacts from extreme storm events. It builds on research findings on perceptions of impacts from storm events experienced by these ports (Becker et al. 2014) and sets out to answer the following questions:

\section{1) How do port stakeholders in Gulfport (MS) and Providence (RI) perceive the range of strategies available to increase resilience for the port?}

\section{2) How does the ability to implement strategies distribute across stakeholder groups?}

Through analysis of in-depth stakeholder interviews, relevant planning and policy documents, as well as the stated missions, mandates and jurisdictions of the stakeholder groups in each location, we evaluate options and consider which stakeholders are best poised to implement specific strategies. Using grounded theory and content analysis, we propose a typology of strategies for port stakeholders and describe how opportunities to implement these strategies distribute across the stakeholders. Though we did not design this study as a comparative case study, we illustrate the stakeholder typology with examples from both ports and, where appropriate, offer 
comparative commentary.

The beginning of this paper defines key terms related to strategies for resilience building and discusses the use of the "stakeholder cluster" as a unit of analysis. We then briefly describe the two case study locations, as well as methods used for data collection and analysis. Next, we present results in the form of seven categories and 128 unique resilience strategies, with examples from the case studies. We then discuss research and practical implications of these results, including general comments on the strategies identified, the stakeholders poised to implement them, and a discussion of potential next steps for research. This paper builds on work conducted in these two ports that catalogues consequences of storm events for port stakeholders. More details on the case studies, methods, and storm consequences may be found in Becker et al. (2014).

\section{STRATEGIES FOR RESILIENCE BUILDING}

Although climate change adaptation motivates this research, we focus specifically on "storm resilience" as a climate change strategy of great interest for seaports, due to impacts to port systems from a combination of sea level rise and changes in storm intensity (Bender et al. 2010, Becker et al. 2012, Grinsted, Moore, and Jevrejeva 2013). In coastal communities, of which ports are a part, concepts of climate adaptation and resilience overlap (Moser and Boykoff 2013). Adaptation, as defined by the Intergovernmental Panel on Climate Change (IPCC), means "any adjustment in natural or human systems in response to actual or expected climatic stimuli or their effects, which moderates harm or exploits beneficial opportunities" (IPCC 2012, p. 36). As articulated by (Lei et al. 2013), an overall sustainable adaptation strategy should both reduce vulnerabilities and also foster resilience and adaptive capacity to future uncertainties. Resilience generally refers to the "ability of a system to absorb disturbance and still retain its basic function and structure" (Walker, Salt, and Reid 2006, p. 1). Vulnerability is defined as, "the propensity or predisposition to be adversely affected ... including the characteristics of a person or group and their situation that influences their capacity to anticipate, cope with, resist, and recover from the adverse affects of physical events" (IPCC 2012, p. 32).

Our research broadly embraces the linked concepts of adaptation and resilience, relying on the stakeholders' own understanding of the terms to develop a catalog of strategies. The research responds to the call for studies on the regional level and examines in more detail strategies for one particular type of facility (the seaport), and one particular impact (more intense storms) from the perspective of the stakeholders themselves (Moser 2010, NRC 2013). Thus, in this research we used a grounded-theory approach (Glaser and Strauss 1967, Charmaz 2003) that allows for categories of resilience strategies to emerge from the perspective of stakeholders themselves and the planning/policy already in place. The purpose of this study was not to test existing frameworks, rather it was to explore how stakeholders themselves consider the range of resilience-building strategies and what opportunities exist for a more holistic engagement of the stakeholders in resilience building for the port 


\section{PORT STAKEHOLDERS}

Scholars and policy makers stress the importance of including stakeholders' perspectives in developing resilience generally (Ward 2001, Bryson 2004, Few, Brown, and Tompkins 2007). Stakeholders of a port may be defined as any group or individual who can affect or is affected by the achievement of the organization's objectives (Freeman 1984). Primarily, ports serve to transfer cargo and/or passengers between a waterway and the shore, however today's ports also serve as profit centers for a variety of businesses, including shippers, shipping agents, energy companies, importers and exporters, and port authorities. They also facilitate transport of energy resources, building materials, finished products, and chemicals that regional economies depend on. Further, ports share ecologically sensitive territory with commercial and recreational users. Thus, ports may also be considered broadly as a cultural element, embedded within and held accountable for the goals of a larger society (Burroughs 2005).

Empirical evidence suggests that support from stakeholders leads to more successful implementation of coastal management decisions (Tompkins, Few, and Brown 2008). Stakeholder input helps assess and identify future socioeconomic impacts (Van Kleef et al. 2006) that can result from hurricanes striking at seaports. Understanding the range of potential resilience options available to stakeholders sets the stage for adaptation. Other research has relied on stakeholder input to assess flood risk (Van Kleef et al. 2006), impacts of sea level rise (Poumadère et al. 2008), and broader regional impacts of climate change (Shackley and Deanwood 2002). Becker et al. (2014) described impacts of storms on seaport stakeholders. However, similar studies have not been conducted to describe how stakeholders perceive the range of strategies that may be implemented to develop seaport resilience.

Most studies of seaport planning confine analysis to the port authority itself or the supply chain, of which the port forms one component (Goss 1990, Haezendonck 2001, Hall and Jacobs 2010). This limitation reflects the tendency for research on ports to focus on logistics, efficiency, and competiveness of the port, rather than the goals and priorities of port stakeholders outside of the supply chain (e.g., the public or the environment). However, as Hall and Jacobs (2007) note, ports deliver services that collectively affect economic growth and stability in their regions, thus providing a public good for a large community. Due to the complexity of port systems and the variety of ways that stakeholders depend upon port functioning, a representative sampling of stakeholder concerns helps develop a richer picture of drivers and stressors that could affect port functioning beyond concerns typically addressed by port operators and port tenants, thus this research incorporates such an approach by examining the port through the lens of the stakeholder cluster.

Strategic management scholars use clusters as a unit of analysis that bounds a group of stakeholders with some common interest (Freeman 1984). Establishing absolute boundaries around this cluster is difficult or impossible, due to the global nature of the transportation network in which ports comprise an integral role. Therefore, the port stakeholder cluster concept here includes the key stakeholders that have an interest in the functioning of a port despite changes in storm intensity and can play some role in planning or decision-making that impacts the port (see Becker et al. 2014). The port stakeholder cluster (Haezendonck 2001, De Langen 2004) may thus be divided into two primary categories: internal and external stakeholders (Figure 1). Those that constitute parts of the port authority organization (e.g., the port operator, 
shareholders, managers, and employees) are internal stakeholders and are generally most concerned with return on investment, shareholder/stakeholder value and/or the creation of wealth. A diverse array of actors and organizations fall into the broader category of external stakeholders.

Figure 1 - Stakeholder cluster (based on Notteboom and Winkelman, 2007)

External stakeholders include primary and secondary categories. Economic/contractual stakeholders are involved in certain port operations such as stevedoring companies, shipping agencies, insurers, ship repair services, port tenants, and the like. Public policy stakeholders include government agencies responsible for transport and economic affairs, as well as environmental agencies, planning departments, and emergency management agencies. These can be further divided into three subcategories: local (e.g., city or county planning and zoning commissions), state (e.g., coastal management programs and departments of transportation), and federal (e.g., the U.S. Coast Guard, the Federal Emergency Management Agency, the U.S. Army Corps of Engineers). Community/environmental stakeholders consist of community groups, neighboring residents, the general public, environmental groups, and others. Academic/research stakeholders also play a role in port planning and development. These include organizations or non-governmental groups that conduct independent work or are contracted by another category of stakeholder. Particularly with regard to resilience or economic development plans, researchers often provide information relevant to the port's planning process.

\section{CASE DESCRIPTIONS}

\section{- GUlfport (MS) AND Providence (RI)}

Variation in ports and the early stage of this type of research make a case study approach an appropriate method for exploratory work to answer nuanced questions about potential resilience strategies available to seaport stakeholders (Flyvbjerg 2006). Because our research focuses on seaport storm resilience, we selected two U.S. ports, Gulfport (MS) and Providence (RI) (Figure 2), with high exposure to hurricanes. We thus expected stakeholders to be familiar with storm resilience issues and the risks associated with hurricanes. Both ports are small-to-medium-sized by shipping throughput and provide jobs, goods, and services to their regional economies and communities.

Figure 2 -- Map of Gulfport and Providence

Gulfport, Mississippi, experienced utter destruction from a 28' storm surge and high winds associated with Hurricane Katrina in 2005. Gulfport recently adopted a plan to elevate the entire port from $10^{\prime}$ to $25^{\prime}$ as a strategy to enhance the port's resilience to storms. This $\$ 140 \mathrm{~m}$ proposed investment in structural resilience was unparalleled. ${ }^{1}$ Thus, we selected Gulfport because we anticipated a high degree of awareness around the impacts of hurricanes (due to the recent Katrina event) and the potential for that port's use of resilience-building strategies.

\footnotetext{
${ }^{1}$ Subsequent to the research reported here, the Port of Gulfport abandoned the structural elevation plan in favor of other investments (MSPG 2012).
} 
Prior to 2011, Providence, Rhode Island, had not experienced a major hurricane since 1954. Providence faces a risk for storm surges in excess of $25^{\prime}$ due to its location at the head of Narragansett Bay. This 20-mile estuary acts as a funnel for storm surge when a hurricane passes to the west. Such a track produces strong southerly winds, forcing water up to Providence Harbor, the narrowest part of the Bay at its northernmost end. The state of Rhode Island has been at the forefront of state-level climate adaptation policy development in the US. Such efforts include the formation of a state Climate Commission (RICCC 2012) (not yet officially designated at the time of the interviews) and the adoption of a sea level rise policy for the state (in draft form at the time of the interviews) (CRMC 2009). These efforts suggested that Providence stakeholders would have a higher awareness of coastal adaptation and resilience issues than those from a state with less public dialog and policy momentum in this area. In addition, the principle author's previous work experience as a policy analyst in Rhode Island focused on the Port of Providence and the creation of state and local policies that directly addressed the port uses. The greater access to stakeholders afforded through existing relationships provided an additional reason for selecting Providence as one of the case studies for this research. Becker et al. (2014) provides a more detailed description of these case study locations.

\section{METHODS}

Methods for these case studies are described in depth in Becker et al. (2014), thus this section provides a very brief overview only. We conducted interviews of 27 stakeholders in Providence and 30 in Gulfport. We identified individual interviewees using people and a snowball sample approach (Table 1 and Table 2). ${ }^{2}$ The members of the cluster self-identified in response to our question: Which organizations have a stake and could (or should) play a role in long-term resilience planning for the port? These stakeholders represent the port cluster, a label that loosely binds the organizations that have a stake in the long-term resilience of a port. In both cases, the majority of stakeholders comprised "public policy" stakeholders, suggesting that interviewees believed that government has primary responsibility for long-term resilience planning. In both cases, however, stakeholders from other categories were also suggested. In Gulfport, however, interviewees did not suggest any stakeholders from the "academic/research" sector.

We presented the stakeholders with a plausible hurricane scenario that outlined wind speeds, storm surge estimates, and included visualizations of the port and surrounding vicinity under such surge heights (see Becker et al. 2014). Interviewees answered questions about potential resilience strategies (i.e., Broadly speaking, what could be done to enhance the resilience of the port in the short or long term?). They discussed both the steps that they currently take, as well as potential strategies that could be employed in the future.

\footnotetext{
${ }^{2}$ In Gulfport, a number of stakeholders could not be interviewed due to scheduling, lack of interest, or other issues. These included: Kansas City Southern Railroad, US Customs, State Senator Wicker, and the Environmental Protection Agency. In Providence, we were unable to interview the Marine Pilots Association and the Rhode Island Oil Heat Institute.
} 
Table 1 - Stakeholders interviewed in Gulfport

Table 2 -- Stakeholders interviewed in Providence

Through web searches and suggestions from interviewees, we also collected all relevant planning and policy documents that addressed both storm resilience and the port in each of the case studies. We found 18 such documents in Gulfport and six in Providence (for complete list, see Becker et al. 2014).

Following transcription, the interviews and documents were coded line-by-line and analyzed using the NVivo qualitative data analysis software package. The analysis used an analytic induction method, a form of grounded theory, described by Ratcliff (1994) as an iterative process that allows for themes and ideas to become evident through the coding process, also allowing for modification of concepts in which ideas were coded and grouped into unique strategies. These unique strategies were then grouped into subcategories and then seven major categories. In some cases, strategies fell into more than one category. In these cases, the strategy was assigned to a sole category based on best fit.

In our analysis, we also evaluated each individual strategy to determine which stakeholder group or groups were poised to implement it. Poised to implement means that the organization or agency has within its mandate, jurisdiction, and mission the ability to devote resources to the implementation of the given strategy (NRC 2010). We based our determination on interviewees' own descriptions of their role with respect to the port as they described it in interviews, as well as through a review of mission statements and organizational objectives for the various stakeholder groups (Becker et al. 2014).

To be clear, this study was not designed to compare these two cases, as there are a wide range of differences between the two in terms of size, governance, type of cargo handled, and political environment. Rather, the study aimed to provide an initial typology of resilience strategies as perceived by stakeholders and in existing plans, as well as to explore how various stakeholders could play a role in resilience-building implementation. Thus, the following section uses examples from both case studies as appropriate, rather than providing a comparison of the two.

We describe the results of the analysis of interviews and documents. Each subsection begins with a general reporting out of the individual strategies identified in the two case studies and a table that organizes the specific strategies by subcategory. We include a short discussion of which stakeholder groups are poised to implement the strategies, indicated by an $\mathrm{X}$ in the accompanying tables. Because the majority of stakeholders fell into the "public policy" category in each of the two seaport cases, we further divided this into the three scales of governance (i.e., federal, state, and local). Throughout the text in each subsection, italics identify names of the specific strategies within each category. Quotes from interviews are identified by quotation marks, but the identify of the individual respondents is not noted, as participants were assured anonymity.

\section{RESULTS - SEVEN TYPES OF PORT RESILIENCE STRATEGIES}

The analysis of interview transcripts and official documents from both Providence and Gulfport 
revealed 128 unique strategies that could be implemented to protect the ports and the port-related interests of the stakeholders. In this section, we ordered strategies based on the number of stakeholders poised to implement strategies within the category, from fewest stakeholders to most. The following sections describe these seven types of strategies with illustrative examples:

1. Building codes and land use regulations

2. Long-range planning

3. Construction and design strategies - on and off port lands

4. Private sector and insurance policies

5. Emergency response, preparation and recovery

6. Research

7. Networks and new ways of thinking

\section{Building codes and land use regulations}

Our analysis revealed 10 unique strategies within "Building codes and land use regulations (Table 3).

Table 3 - Table of Building Codes and Land Use Regulation Strategies

Specific strategies included: prohibit the use of erosive fill, create tighter controls on development in floodplains, and increase freeboard requirements for structures. Most of these strategies have long-term benefits (i.e., more than 20 years) and reduce the overall vulnerability of the port from the impacts of storm events both in the near term and decades into the future. Because of the long-term scope of these regulatory strategies they must be based upon good scientific projections about the probability of future storm events, flooding, and inundation due to sea level rise that will occur throughout the functional lifespan of the structure or land area. Because of uncertainties inherent in such projections (Stocker 2013), the creation and implementation of these types of strategies could prove difficult because of the costs and politics associated with making such changes.

In Providence, the industrial waterfront consists of much aging infrastructure. As noted in one report, "a significant portion of the region's critical facilities and coastal infrastructure located in the floodplain is not protected or was built before the current building standards were adopted in the 1970s" (CRMC 2011, p. 19). Only a permit application to significantly change or improve those structures would trigger a requirement to bring such structures into compliance with current building standards. Thus, interviewees suggested that many structures would remain unfit for current conditions even without impacts associated with climate change. Local or state government entities would likely take the lead on changing building codes and land use regulations in order to enhance port resilience. Though respondents were asked to think specifically about the port, many of the strategies they mentioned could also enhance resilience for the broader waterfront community.

\section{Stakeholder implementation}

All ten of these strategies exist within the jurisdiction or mandates of state agencies, such as the Coastal Resources Management Council (CRMC) in Rhode Island and the Mississippi 
Department of Transportation in Gulfport, indicating that this type of strategy implementation rests primarily with public policy makers at the state level. In Providence, strategies like conditioning new permits on debris cleanup standards could be implemented by the CRMC to help reduce the amount of debris that accumulates during a storm event. A state law conditioning new permits on debris cleanup standards, for example, could be a way to give the CRMC the authority to address storm debris problems throughout all of the coastal areas of the state. Other ideas, like creating performance measures, would also be implemented by state policy agencies such as the State Building Code Commissions or through local codes or zoning ordinances.

Some ideas generated by stakeholders from one case study could be applied to the other, suggesting opportunities for exchanging best practices and lessons learned. For example, in Providence, fitness of purpose regulations authorize the CRMC to inspect waterfront facilities and require upgrades for docks and wharves to ensure they are adequate for their intended use. This type of regulation could also be implemented in Gulfport where the state coastal agency (the Dept. of Marine Resources) played a less significant role in port regulation than its counterpart in Rhode Island. It should be noted, however, that while interviewees from Providence felt that the new fitness of purpose regulations served an important role, Rhode Island's state jurisdiction for fitness of purpose only pertains to structures seaward of the high tide line. Thus, the regulations do not cover petroleum storage tanks or any other port facility infrastructure located upland of the mean high tide line. As one state official put it, "There's a gap in mandates and jurisdictions, so a lot of the facilities (e.g., tanks, berms, petroleum transfer facilities) are outside of our jurisdiction."

\section{Long-range planning}

According to respondents and documents, a stronger focus on long-range planning (Table 4) would be an important component of enhancing resilience for each port. We categorized planning strategies with a $20+$ year time horizon as "long-range."

Table 4 - Table of Long Range Planning Strategies

We grouped the six specific long-range planning strategies into three subcategories: 1) general hazard mitigation plans; 2) specific climate adaptation plans; and 3) the incorporation of resilience principles into existing planning efforts. Both ports already had well-established general hazard mitigation plans that addressed disaster preparedness and response, the specifics of which are discussed in Section 5. However, most of these existing plans addressed the port in a cursory manner, if at all. None considered long-term implications of climate change. The second type of long-term strategy suggestion - the creation of new specific climate adaptation plans - ranged from adaptation plans for individual facilities to regional plans that would address impacts and planning efforts for multiple ports in multiple states. Respondents also discussed a third type of long-term planning strategy, the need to better incorporate resilience into existing planning efforts, such as the statewide guidance plans and transportation plans. This could be accomplished by creating new climate adaptation sections for these plans or by weaving new language and content into existing objectives. As one Rhode Island respondent put it, "I think that our [30-year] Statewide Plan needs to consider this sort of scenario much more [and] give it higher priority." 


\section{Stakeholder implementation}

Often, longer time horizons do not align with the planning cycles of individual ports or private firms that typically extend out to about 10 years (Becker et al. 2014). Planning beyond 10 years involves many uncertainties, such as potential market shifts, changes in regulations and policy, and technological advances, among other variables. ${ }^{3}$ Thus, six of the long-term planning efforts exist within the domain of state entities such as Statewide Planning and the CRMC (e.g., Providence) and the Mississippi Development Authority (MDA) and Mississippi Department of Transportation (e.g., Gulfport). Unlike Providence stakeholders, Gulfport respondents did not emphasize long-range planning when discussing resilience.

Respondents raised many issues around climate change impacts when they discussed long-range resilience planning. In general, Providence respondents also expressed more concern about the impacts of climate change and its implications for long-term planning. Many Gulfport respondents still felt overwhelmed by the effects of Hurricane Katrina, expressing resignation to the idea that another storm of Katrina's magnitude would simply be impossible to recover from. Thus, paradoxically, Providence respondents may have been in a better position to think about long term planning due to the very fact that they had not recently experienced such a major storm event and felt less paralyzed by the knowledge of its potential for destruction.

\section{Construction and design strategies (on and off port lands)}

Our analysis revealed a total of 24 individual strategies that we categorized as Construction and design strategies (Table 5), comprised of developing and implementing physical changes either on or off the port in order to enhance resilience. We divided construction and design strategies into two subcategories: 12 Construction and design strategies ON port lands and 12

Construction and design strategies OFF port lands. ON port lands refers to strategies that could be implemented within the physical boundary of the port itself, as opposed to a strategy that would be developed somewhere offsite (e.g., a storm barrier).

\section{Table 5 - Table of Construction and Design Strategies}

All 12 of the $O N$ port lands strategies could be implemented by the internal port stakeholder (Waterson Terminal Services in Providence and the Mississippi State Port Authority in Providence) and involve the use of stronger building materials and hardening structures against the effects of wind and storm surge as well as building/designing submersible structures that allow for flooding followed by draining or pumping dry.

Interviewees suggested other construction and design strategies ON port lands, such as the use of sacrificial structures designed to give way under a load. For example, breakaway walls built at ground level allow water to pass through a space in case of a flood. These non-load bearing walls break down but do not cause the collapse of the entire building. In Gulfport, most respondents also discussed elevating the entire footprint of the port to raise the whole port up and out of the floodplain. At the time of the interviews, the Port of Gulfport approved a formal plan

\footnotetext{
${ }^{3}$ Note that there are exceptions (e.g., The Port of Rotterdam), but generally speaking 10 years is the typical planning horizon as reported in a survey of port authorities (Becker et al. 2012).
} 
to do exactly that, even though that plan was later abandoned in order to reallocate funding for shorter-term port expansion goals (MSPG 2012). In Providence, the port already had installed fencing designed to accommodate storm surges and prevent the spread of debris.

Implementation of the twelve Construction and design strategies OFF port lands could also result in a more resilient port. Most of these strategies refer to major projects that would likely extend beyond the jurisdiction or mission of the internal port stakeholder. These include major new infrastructure initiatives, such as constructing breakwaters, building barriers/dikes, and relocating the entire port. Respondents in Gulfport, for example, mentioned the need to restore offshore barrier islands that protect the coast and wetlands and slow hurricane-force winds. Enhance resilience of the infrastructure connecting to the port was also suggested. Many respondents in both case studies mentioned that the port does not function in isolation from its connecting infrastructure, and thus a port is only as resilient as its connecting critical infrastructure (e.g., roads, bridges, rail). For example, Gulfport respondents mentioned that tunneling and elevating the roadway to the port had been considered as part of the post-Katrina rebuilding plans, though no entity had initiated such plans at the time of the interviews.

\section{Stakeholder implementation}

Implementing construction and design strategies $O N$ port lands would likely be within the authority of the port operators themselves, as they are ultimately the decision makers for final construction specifications for port structures. However, the port operator may be compelled to implement these strategies through a number of external mechanisms (e.g., insurance requirements, building codes or funding stipulations). Though interviewees mentioned these types of involuntary mechanisms when discussing construction and design, we categorized the involuntary mechanisms separately from the voluntary adoption of specific construction or design specifications.

The state and federal government emerge as key stakeholders to implement the OFF-port lands construction and design strategies, as constructing and modifying features off of port lands would most likely be federally funded and/or state sponsored because the cost of such investments would typically exceed the financial capacity of other stakeholder organizations. Since most of these types of OFF-port projects cross federally managed waterways, the U.S. Army Corps of Engineers (USACE) would likely serve as lead agency. However, any major project on this scale requires substantial input from many government agencies and other stakeholders in the region, thus ultimately all stakeholders would play some role in the design and implementation.

\section{Private sector and insurance policies}

The ten private sector and insurance policies strategies identified in our analysis (Table 6) include actions that could be taken by the port, private companies directly engaged with the port, and by insurance companies that contract with the port or its tenants to minimize their own risk and liability. 
Table 6 - Table of Private Sector and Insurance Policies

Specific policies for the port and port businesses include: develop climate adaptation plans, factor resilience into normal operations and management programs, appropriate adjacent properties to minimize damage to neighboring non-port interests, and purchase additional insurance coverage. This strategy category also includes actions that the insurance sector could take to encourage port resilience. All businesses associated with the ports carry some amount of insurance in case of a major storm event, and a number of strategies focus on improving the role the insurance industry plays in managing risk. Insurance inspections on site, for example, could identify vulnerabilities of structures and infrastructure. Interviewees also suggested the development of new insurance incentives for going above and beyond the minimum requirements set by local building codes. Stakeholder suggestions regarding insurance turned out to be far more extensive and complicated than we anticipated. Since many individual businesses comprise the port, each with multiple types of policies, enhancing resilience for the port through insurance incentives requires alignment between and among insurance policy provisions. Significantly, in both Gulfport and Providence, the insurance companies interviewed indicated that their premium calculations did not account for any future changes in sea level or storm intensity. We address this in more detail in the discussion section.

\section{Stakeholder Implementation}

Some strategies, such as creating a climate change adaptation local partnership to assist the port in preparation for climate impacts could be implemented by any of the stakeholders on the local level, including community groups and external/contractual stakeholders, while others (e.g., factor resilience into normal operations and maintenance program and purchase additional insurance coverage) would most likely be implemented by the internal port stakeholder. The insurance firms could implement many of the insurance-related strategies as a way to both build resilience and reduce their own liabilities. Our research did not address incentives for the private sector to invest in these types of strategies.

\section{Emergency preparation, response and recovery}

When asked to discuss possible resilience-building strategies, many interviewees in both Providence and Gulfport focused almost entirely on emergency preparation, response, and recovery strategies (Table 7 ). Such strategies focus on readying the port immediately prior to a storm, as well as actions during and immediately following the storm to manage a disaster's impacts.

Table 7 - Table of Emergency Preparation, Response, and Recovery Strategies

We organized the 33 emergency preparation, response, and recovery strategies into five subcategories, as follows.

First, business continuity planning strategies minimize the downtime that a particular company experiences during and after a storm event. Specific actions suggested include data storage plans such as backing up data to an offsite location. Contracts and agreements between companies negotiated in advance of a storm build in redundancy and increase the efficiency of cleanup. For example, respondents in Gulfport described how cleanup efforts slowed after Katrina due to the 
bidding process that was required in the selection of contractors to carry out cleanup efforts. The bidding process required by state law alone took several weeks, thus delaying the start of actual cleanup work. The state now bids out the cleanup contracts in advance so that cleanup can begin immediately after a storm event. Another Gulfport interviewee explained how companies worked together to facilitate the supply of truck chassis required to move shipping containers out of the Port of Gulfport after Katrina. Truck chassis were in short supply and had to be swapped between companies in order to move containers off port grounds more quickly. In both cases, pre-storm contracts could have facilitated more efficient recovery.

Second, Drills \& pre-event trainings include tabletop exercises, usually led by the local U.S. Coast Guard office, and involve many port representatives. These exercises comprise a major part of existing resilience strategies in both Gulfport and Providence. In both ports, numerous stakeholders participate in emergency drills and training conduct by the local U.S. Coast Guard offices, though these drills often focus on non storm-related emergencies (i.e., terrorist attacks or oil spills), they can enhance local effectiveness in dealing with storm events.

Third, post-storm actions include actions immediately after the storm passes, such as attending to the needs of port employees who may be facing the loss of their homes or displaced families generally.

Fourth, Response and recovery guidance strategies include creation of communications plans, evacuation procedures, debris management plans, and guidance for use of the port facility as a staging area for the first responders.

Finally, Storm preparations include the many specific actions that could prepare the port for a storm event. Examples include securing port equipment in place, shutting down waterway traffic, evacuation of the port, and moving equipment to higher ground. Gulfport respondents discussed their experience with Hurricane Katrina and the many issues they encountered during and after the storm. Along with elevating the port, a comprehensive evacuation plan stood out as the resilience strategy most strongly considered. Evacuation of the port includes moving personnel, cargo, and equipment to an inland facility about three miles away from the port. In Providence, evacuation was also considered. However, there was no formal plan, nor a designated inland location for port equipment and cargo, and there was the extra challenge of having to relocate bulk cargo like salt or coal piles (as opposed to containers that are more easily transported). As stated by a Providence respondent,

During [a hurricane scenario], I don't think [the port] would have enough time or forewarning to relocate and move [the coal, scrap metal, or other bulk products] even knowing that a Category 3 hurricane [was coming]. They just wouldn't have enough time to move it. And [even if they did], where would they put it?

In Gulfport, one respondent described preparing for the storm by placing shipping containers as barriers in front of vulnerable buildings. They also suggested that the port inventory could be managed to reduce stock levels well before an oncoming storm, thus minimizing the evacuation effort and ensuring that cargo normally stored at the port would not turn into debris. 


\section{Stakeholder implementation}

Many stakeholders could implement these types of strategies. The port itself could implement all 26 and economic/contractual stakeholders could implement 23. Many of the strategies require engagement of multiple stakeholders. Strong collaborations were already in place in both Gulfport and Providence, with stakeholders acknowledging the dominant role of the U.S. Coast Guard. In both case studies, respondents provided examples of successful emergency management exercises. As one respondent from Providence stated:

We've got a plan ... Since we're under heavy Coast Guard rule of thumb; they're pretty much taking a lead as far as [emergency] response, as far as giving us the heads up, the early warming. Basically, the port's plan is to move the equipment to higher ground.

\section{Research}

The 13 Research strategies (Table 8) include ways to build a better understanding of the aspects of risk and vulnerability, as well as the costs and benefits of various risk-mitigation responses.

\section{Table 8 - Table of Research Strategies}

Respondents suggested vulnerability studies, scenario exercises, improving forecasting, and other efforts that could be conducted by government, private sectors and/or academia. Some respondents cited a need for better hurricane forecasts and better floodplain mapping. Others discussed a general lack of understanding of port vulnerability and how new studies on best practices might benefit the ports directly. One respondent also suggested research to help planners identify potential funding streams, noting that, "the biggest thing that could benefit our ability to plan for and respond would be to identify a funding stream to support those efforts that would not also drag the local economy down."

\section{Stakeholder implementation}

Opportunities to implement Research strategies exist across the entire port stakeholder cluster. Some of the strategies could be sponsored by one stakeholder, but carried out by another (e.g., a research institute or university). In Providence, both the University of Rhode Island (URI) and Brown University were identified as "Research/academia stakeholders." Both institutions had conducted research efforts around the Port of Providence, along with URI's Coastal Resources Center. The Center took the lead on drafting climate adaptation policies and a working waterfront policy, while the Ocean Engineering department of URI conducted an extensive survey of debris potential around the port area. In Gulfport, our snowball sample did not identify any research institutions as already a part of the stakeholder cluster. However, an assessment conducted by Curtis and colleagues (2007) suggests some best practices for rebuilding certain structures at the port. In addition, a study conducted by students at Columbia University aimed to inform the Port of Gulfport and its surrounding communities on the essential elements of port sustainability and how those elements could be incorporated into the port's planning process (Morse 2011). The latter study used case studies of other ports to inform best practices, including 
many that we include and categorize in our study (these were: Develop a climate change adaptation plan, Establish a climate change adaptation local partnership, and Join international networks related to port climate change adaptation). The port or another stakeholder may contract for such research; the studies may also be spearheaded by the research institute itself or implemented through a partnership arrangement between stakeholder groups.

\section{Networks and new ways of thinking}

Networks and new ways of thinking emerged as a category that captures broader strategies to help create the conditions necessary for building port resilience. These strategies include ideas for enhancing access to and sharing of information, as well as shifting focus to proactive actions that enable resilience building. We sorted thirty-two Networks and new ways of thinking (Table 9) strategies into the following five subcategories: collaborations, empower government, improve information flows, lengthen planning horizons, and shifts in thinking. Ideas for collaborations included: form new collaborations amongst government agencies, create climate monitoring offices and climate commissions, and improve information flows between stakeholder groups.

Table 9 - Table of Networks and New Ways of Thinking Strategies

Interviewees also discussed ways for government to build port resilience. For example, one respondent suggested enhancing the Federal Emergency Management Agency (FEMA) Hazard Mitigation program to prioritize disaster mitigation. At the time of interviews, FEMA's mission with respect to disasters consisted of four focus areas: mitigation, preparation, response, and recovery (FEMA 2013). According to respondents, FEMA provided less funding for mitigation activities than for those in its other focus areas.

Interviewees also suggested that enhanced insurance coverage be required as a prerequisite for federal aid for post-storm rebuilding. As noted by one respondent, the National Flood Insurance Program (NFIP) offers discounts on insurance if structures are built with freeboard higher than the minimum required. Though this approach is in part an insurance strategy and could also fit into the Insurance and Private Sector category above, we include it in the empower government subcategory because it is a government-based policy that must be implemented from within the NFIP, rather than one that could be created solely within the insurance or private sectors. Other ways of empowering government include the authorization for development of stronger state regulations. For example, in Rhode Island, a draft "Hazards Chapter" in the Special Area Management Plan recommended that provisions be incorporated "into design and permitting of water-based projects to address preparedness, response and recovery of hazards related to hurricanes and sea level rise (Statewide) (CRMC 2011, p. 2). At this point, however, the authority of the CRMC only extends landward to the high-tide line. Thus, in order for CRMC to develop regulations along these lines, they would need the additional state legal authority over projects that are water-based, but not necessarily seaward of the high-tide line.

\section{Stakeholder implementation}

Networks and new ways of thinking require engagement with all stakeholders across the cluster. These kinds of ideas lay the foundation for a more holistic approach to resilience planning for 
infrastructure, such as ports. Many of these ideas highlight the importance of collaborations and improved information flows. Though many do not build resilience in a direct way (i.e., they do not directly reduce level of damage), they can help a port system bounce back more quickly following a major storm event and bring all stakeholders to the table for planning.

\section{DISCUSSION}

The preceding sections outlined seven categories of port resilience strategies and suggested examples of how various stakeholders could play a role in implementing these strategies. We next discuss these results in aggregate and implications for our two original research questions.

\section{Q1 - How do port stakeholders in Gulfport (MS) and Providence (RI) perceive the range of strategies available to increase resilience for the local port?}

In sum, we identified 128 resilience strategies through interviews with stakeholders and a review of relevant documents. For each category of resilience strategy, a summary figure indicates the total number of strategies identified in interviews and documents (in parentheses after the category title), which stakeholders are best poised to implement the given strategies (indicated by colored dots), as well as how many of those strategies could be implemented by each given type of stakeholder group (indicated by number inside dot) (Figure 3 and Figure 4).

Figure 3 -- Stakeholder groups poised for leadership (Version 1)

Figure 4 -- Stakeholders poised for leadership (Version 2)

This analysis and the resulting typology provide guidance and framing for considering the broad range of resilience strategies available to the port stakeholder cluster. Though many strategies can build port resilience, most stakeholders we interviewed focused on disaster response and management, rather than proactive steps that could be taken to build resilience over the long term (e.g., storm barriers, research efforts, collaborations). This largely reactive mindset can be seen in the number of strategies (33) that fell into the emergency preparation, response, and recovery category. Many of the respondents spoke almost exclusively about these types of strategies, and did not discuss the broader issues of, for example, long-term planning for resilience. This imbalance may be due to well-established emergency response roles: there are clear goals (e.g., remove people and hazards) and clear tasks to be managed (e.g., clean up debris, re-establish utilities, etc.). Measuring the success and determining which organization has responsibility to implement the longer-term or softer strategies can be more opaque, as their success occurs only when an anticipated problem or impact is avoided: it is much more difficult to measure and quantify, for example, the payoff of a good land use policy or building code (Moser and Boykoff 2013).

The empirical data from our interviews and document review produced a new set of resilience strategy categories that complement those of more generalized models such as that of Travis, Cheong, and the NRC (Travis 2009, NRC 2010, Cheong 2011). For example, Travis' "Physical protection and barrier to make places safe from the hazard" includes many strategies that we categorized as Construction and design on/off port lands. Similarly, Travis' "Relief and insurance mechanisms" is similar to our category of Insurance strategies. However, we also 
suggest that taking a stakeholder-based approach at a local level to identify strategies can lead to a more relevant typology for the stakeholder cluster. For example, Networks and new ways of thinking and Research strategies might have been overlooked if a typology such as Travis' or Cheong's were employed. When stakeholders were asked, "what measures could be implemented to build resilience," the opportunity to think broadly about the question resulted in an analysis that included many strategies that would lead to higher levels of resilience (e.g., developing new collaborations between stakeholders) though perhaps not directly reducing physical vulnerability.

\section{Q2 - How does the ability to implement strategies distribute across the various stakeholder groups?}

As noted by the NRC, effective climate adaptation will require all types of decision makers and stakeholders to participate (NRC 2010). Using the NRC (2010) report as a template, we also reviewed the management responsibilities described in interviews, as well as the mandates, jurisdictions, and missions of organizations interviewed and found that stakeholders in the state public policy and internal port were poised to take leadership for the highest number of strategies (Figure 5), but every stakeholder group was poised to implement at least some of the strategies. This suggests that a more holistic approach to planning could incorporate actions from all stakeholders, thus spreading the burden (and cost) for resilience building across those who would reap some benefit from a more resilient port.

Figure 5 -- Summary of stakeholders and strategies

Many strategies that reduce risk and develop long-term resilience can be implemented incrementally, over time. These will likely occur in an "evolutionary" manner as sea levels rise and storms intensify and patterns change. As Kates et al. (2001) describe, these more incremental strategies may be thought of as "extensions of actions and behaviors that already reduce the losses or enhance the benefits of natural variations in climate and extreme events." For example, stakeholders could conduct research activities, change private sector and insurance policies; build networks and new ways of thinking, and implement construction and design strategies over time. We also found three "transformational adaptation" strategies; strategies much larger in scale that may transform a place or initiate a major shift in location (Kates, Travis, and Wilbanks 2012, p. 7156): the construction of a dike, moving the port, and abandoning the port entirely. However, interviewees did not consider these transformational strategies viable. As one interviewee put it, "nobody wants to talk about things that have huge price tags. Another agreed, A Thames Barrier [type solution] would be foolproof [for protecting the port], but the government isn't going to spend the money."

Though a thorough discussion of the barriers to implementing these strategies is beyond the scope of this paper (for more on barriers, see Moser and Ekstrom 2010), many interviewees volunteered that lack of leadership is a barrier. They reported that building port resilience should be a priority, but were unclear about which stakeholders should take the lead. In addition, many pointed to more pressing priorities of the day to explain why more has not yet been done to build resilience. When compared to the other competing demands for staff resources and budget, developing, leading and implementing port resilience strategies was viewed as less urgent than other more immediate needs. For example, in the public policy sector, agency representatives 
indicated that their resources were already stretched thin and that building long-term resilience for the port was not a priority. Although stakeholders described many strategies for building resilience, the incentive structure for investing in implementation was not clear to respondents.

Given the long time horizons and uncertain projections for storm probabilities due to climate change, planning for a resilient port will require stakeholders to assume new roles in the resilience-building process (Ng, Becker, and Fischer 2013). Port planners need to engage more with stakeholders during the port's strategic planning process as a way to develop deeper understanding of the full range of potential resilience strategies and how to overcome barriers to adaptation (Cone et al. 2013). In addition, this research suggests a more active role for external stakeholders; indeed external stakeholders have much to lose when the next hurricane hits the port and developing a high level of resilience may not be achievable by the port alone.

We envision this research as a contribution to the multi-step process of enhancing port resilience to the kind of storm events that scientists expect will increase with climate change(NCA 2014, Horton et al. 2014). Strategies identified here deserve further evaluation to better understand the costs (to whom) and benefits (to whom) of each. Through a stakeholder-informed process, more complete information can help validate some of the assumptions we make regarding which organizations are poised to take leadership roles. Choosing and implementing resilience strategies involves tradeoffs, leadership, and investment of time, energy and resources. The resilience strategy categories derived from these case studies may be used in the formulation of ranking and prioritizing exercises that could involve many of the types of stakeholders who participated in this research.

\section{CONCLUSIONS}

Though these findings suggest that the major burden for implementing port resilience strategies rests with the port and the state, there exists a significant role for the other stakeholders in the port cluster. Port authorities can improve the resiliency of their own facilities through better construction and designs and more robust emergency management plans. State agencies could improve port construction standards, including building and land use codes, to help create infrastructure that is more resistant to the kinds of storm events that are expected with climate change. The insurance industry, together with state and federal regulators, could create stronger links between insurance premiums and resilience actions, thereby establishing incentives to increase port system resilience. The maritime transportation infrastructure system should be considered as a whole to prevent a "weak link" effect of losing one component (e.g., the rail link) while other parts of the system are built to an increased resiliency standard. Creating a master plan that considers the entire stakeholder cluster and lays out a strategy implementation timeline for the next 100 years could go far to help inform all stakeholders of the benefits of a more resilient port.

Managing the design and implementation of long-term resilience strategies requires strong leadership from one or more stakeholders. Such leadership could come from the port itself or from a state agency, so-called "boundary organizations" may also be well suited for taking a leadership role in developing an overall planning effort through fostering knowledge networks between researchers and decision makers (Bidwell, Dietz, and Scavia 2013). Boundary 
organizations, such as the National Sea Grant Program and NOAA's Regional Integrated Science Assessments (RISA) programs, can maintain a neutral position while bringing stakeholders together to better understand impacts, strategic options, and shape a process to determine a best course of action for strategy selection and implementation. In Rhode Island, Rhode Island Sea Grant and Coastal Resources Center at the University of Rhode Island have served this role for other multi-stakeholder planning efforts (CRC 2014) .

The potential to link actionable research to port system resiliency is strong, and scoping that research so that it is salient and timely will require stepped up discussions, leadership, and ongoing consultation among stakeholders and researchers. This study provides an initial step toward a more thorough planning process that can evolve to better prepare seaports for the new climate conditions already experienced and those expected in the future.

\section{TABLES AND FIGURES}

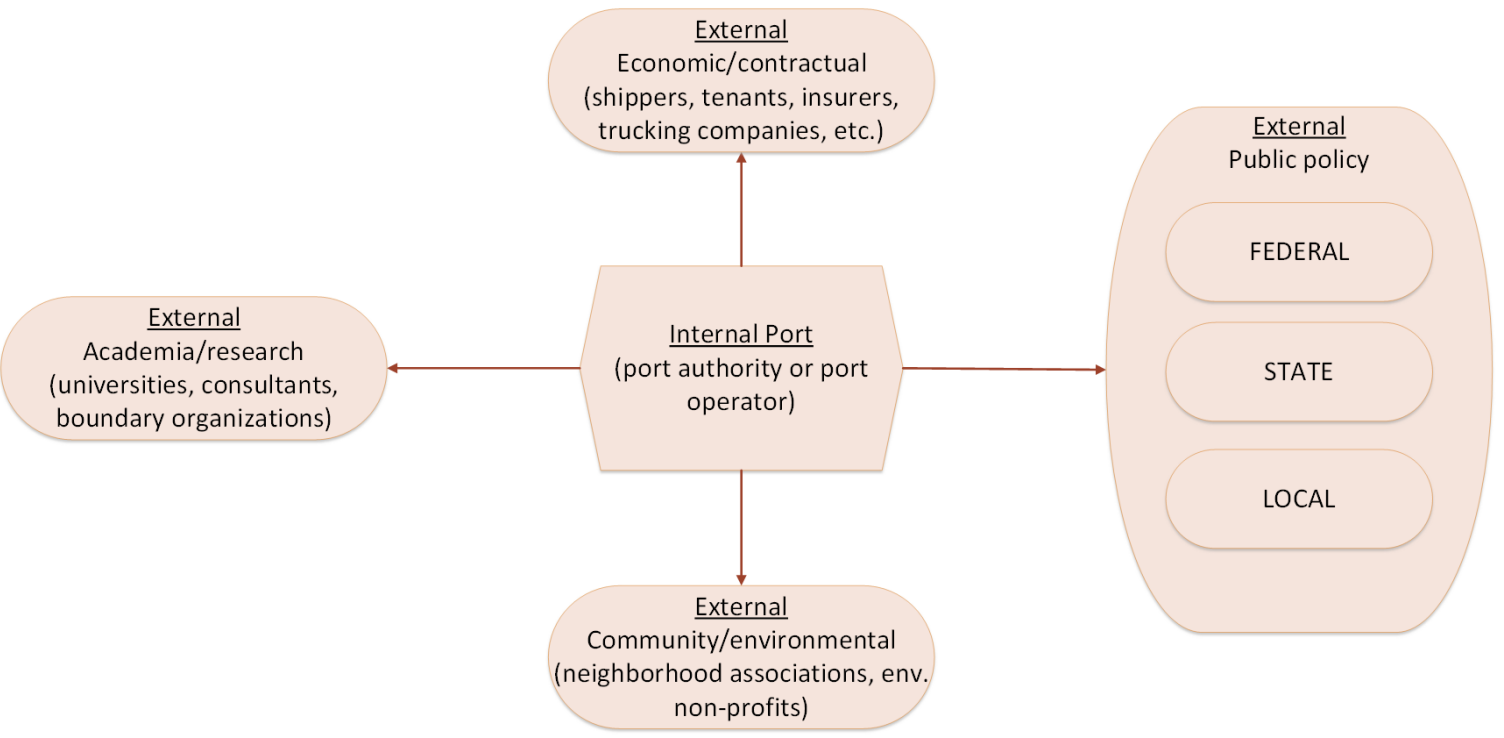

Figure 6 - Stakeholder cluster (based on Notteboom and Winkelman, 2007) 


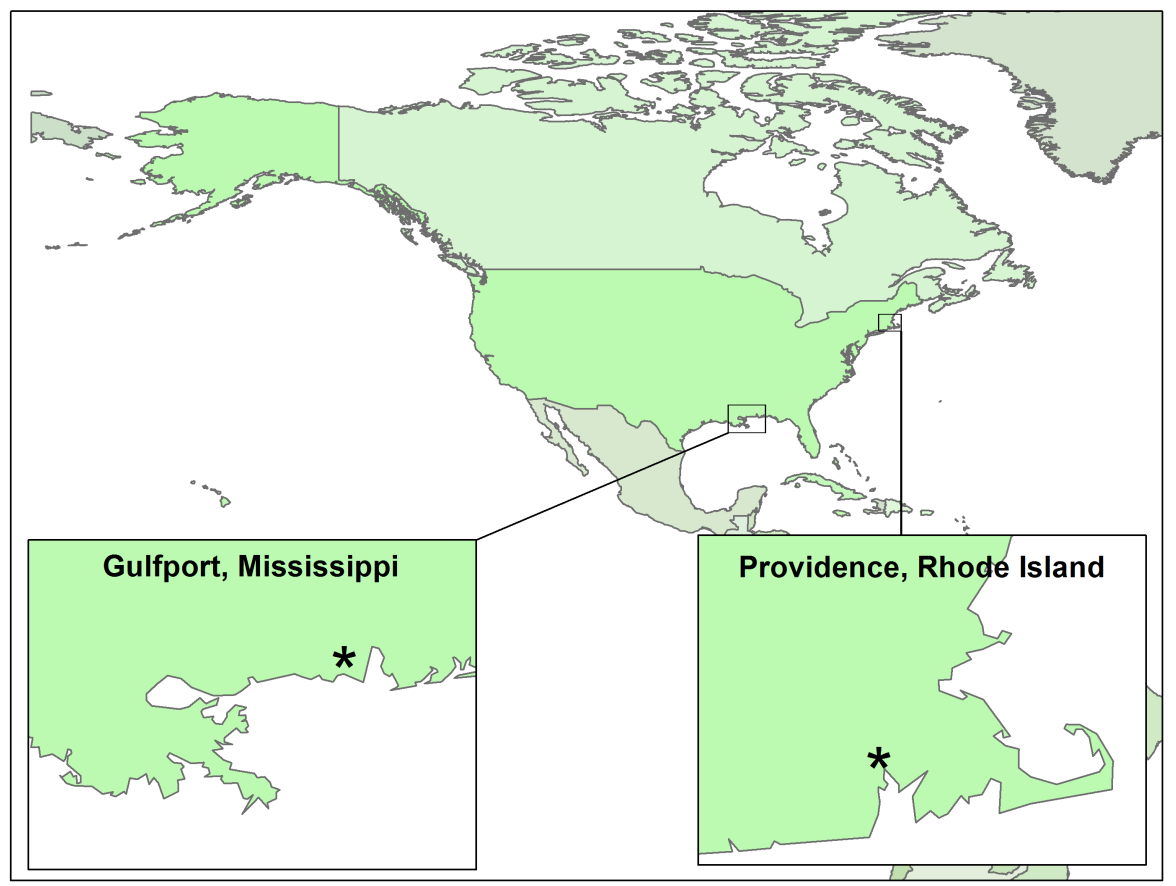

Figure 7 -- Map of Gulfport and Providence

Table 10 -- Stakeholders interviewed in Gulfport

\begin{tabular}{|c|c|c|c|}
\hline Stakeholders & Organization interviewed & Port interests & Interview: \\
\hline \multirow{2}{*}{$\begin{array}{l}\text { Internal port } \\
\text { stakeholders }\end{array}$} & $\begin{array}{l}\text { Mississippi State Port Authority } \\
\text { (MSPA) }\end{array}$ & $\begin{array}{l}\text { Make port an economic engine for the state, } \\
\text { provide jobs }\end{array}$ & 3 \\
\hline & $\mathrm{CH} 2 \mathrm{M}$ Hill (Contracted by MSPA) & $\begin{array}{l}\text { Provide program management and support for } \\
\text { restoration project }\end{array}$ & 1 \\
\hline \multirow{4}{*}{ Public policy (federal) } & US Coast Guard (USCG) & $\begin{array}{l}\text { Facilitate the navigational needs of the port and } \\
\text { shipping, facilitate storm operations }\end{array}$ & 1 \\
\hline & $\begin{array}{l}\text { US Army Corps of Engineers } \\
\text { (USACE) }\end{array}$ & $\begin{array}{l}\text { Facilitate maritime commerce, protect marine } \\
\text { resources, maintain ship channel }\end{array}$ & 2 \\
\hline & $\begin{array}{l}\text { US Federal Emergency } \\
\text { Management Agency (FEMA) }\end{array}$ & $\begin{array}{l}\text { Facilitate disaster preparation, mitigation, } \\
\text { response, and recovery }\end{array}$ & 5 \\
\hline & $\begin{array}{l}\text { National Oceanic and Atmospheric } \\
\text { Association (NOAA) }\end{array}$ & Provide weather and climate data & 1 \\
\hline
\end{tabular}




\begin{tabular}{|c|c|c|c|}
\hline \multirow{6}{*}{ Public policy (state) } & Gulf Regional Planning Commission & $\begin{array}{l}\text { Long range planning for regional transportation } \\
\text { system }\end{array}$ & 1 \\
\hline & Gulf of Mexico Alliance (GOMA) & Coastal community resilience & 1 \\
\hline & Mississippi Emergency & Review port project applications & 3 \\
\hline & Management Agency (MEMA) & & \\
\hline & $\begin{array}{l}\text { Mississippi Department of } \\
\text { Transportation (MDOT) }\end{array}$ & $\begin{array}{l}\text { Construction and maintenance of connecting } \\
\text { infrastructure }\end{array}$ & 1 \\
\hline & $\begin{array}{l}\text { Mississippi Department of Marine } \\
\text { Resources (MDMR) }\end{array}$ & $\begin{array}{l}\text { Activities at the port that impact coastal waters } \\
\text { or wetlands }\end{array}$ & 3 \\
\hline \multirow{3}{*}{ Public policy (local) } & Harrison County Civil Defense & $\begin{array}{l}\text { Facilitate local emergency response, including } \\
\text { evacuations }\end{array}$ & 1 \\
\hline & City of Gulfport & Represent citizens of the city in port decisions & 1 \\
\hline & $\begin{array}{l}\text { Southern Mississippi Planning and } \\
\text { Development }\end{array}$ & $\begin{array}{l}\text { Grant facilitation for transportation project } \\
\text { adjacent to port }\end{array}$ & 1 \\
\hline Community groups & STEPS Neighborhood Group & $\begin{array}{l}\text { Protect adjacent communities, advocate for jobs } \\
\text { growth }\end{array}$ & 1 \\
\hline
\end{tabular}


Table 11 -- Stakeholders interviewed in Providence

\begin{tabular}{|c|c|c|c|}
\hline Stakeholders & $\begin{array}{c}\text { Organization } \\
\text { interviewed }\end{array}$ & Port interests & Interviews \\
\hline \multicolumn{4}{|l|}{ Internal Stakeholders } \\
\hline Internal Stakeholders & $\begin{array}{ll}\text { Waterson } & \text { Terminal } \\
\text { Services } & \end{array}$ & Generate profit & 3 \\
\hline \multicolumn{4}{|l|}{ External Stakeholders } \\
\hline \multirow{4}{*}{$\begin{array}{c}\text { Economic/contractual/ } \\
\text { private firms }\end{array}$} & Univar & Port tenant & 1 \\
\hline & $\begin{array}{l}\text { Affiliated Insurance } \\
\text { Managers }\end{array}$ & Reduce risks and liability & 1 \\
\hline & Moran Shipping Agency & Service port and users & 2 \\
\hline & Promet Marine Services & Repairs to ships and docks & 1 \\
\hline \multirow{3}{*}{ Public policy (Federal) } & US Coast Guard & $\begin{array}{l}\text { Facilitate maritime commerce, protect marine } \\
\text { resources, maintain ship channel }\end{array}$ & 1 \\
\hline & $\begin{array}{l}\text { US Army Corps of } \\
\text { Engineers }\end{array}$ & $\begin{array}{l}\text { Facilitate maritime commerce, protect marine } \\
\text { resources, maintain ship channel }\end{array}$ & 2 \\
\hline & $\begin{array}{l}\text { National Flood Insurance } \\
\text { Program }\end{array}$ & $\begin{array}{l}\text { Facilitate disaster preparation, mitigation, } \\
\text { response, and recovery }\end{array}$ & 1 \\
\hline \multirow{6}{*}{ Public policy (State) } & $\begin{array}{l}\text { RI Coastal Resources } \\
\text { Management Council }\end{array}$ & Regulate coastal zone & 3 \\
\hline & RI Statewide Planning & Transportation and land use planning & 1 \\
\hline & & Generate jobs, economic development & 1 \\
\hline & RI Dept. of Transportation & Maintain/improve highways/bridges & 1 \\
\hline & $\begin{array}{l}\text { RI Dept. of Env. } \\
\text { Management }\end{array}$ & Environmental concerns & 1 \\
\hline & RI State Senate & & 1 \\
\hline \multirow{3}{*}{ Public policy (local) } & Providence Planning Dept. & Promote city interests, generate taxes, zoning & 1 \\
\hline & Providence Emergency & Emergency response & 1 \\
\hline & Providence Fire Dept. & Emergency response & 1 \\
\hline Community & Save the Bay & $\begin{array}{l}\text { Protect adjacent communities, advocate for } \\
\text { jobs growth }\end{array}$ & 1 \\
\hline \multirow{3}{*}{ Research/academic } & Brown University & Provide research capabilities & 1 \\
\hline & $\begin{array}{l}\text { RI Coastal Resources } \\
\text { Center }\end{array}$ & Provide research capabilities & 1 \\
\hline & URI & Provide research capabilities & 1 \\
\hline
\end{tabular}


Table 12 - Table of Building Codes and Land Use Regulation Strategies

\begin{tabular}{|c|c|c|c|c|c|c|c|}
\hline \multirow[b]{2}{*}{ Building codes and land use regulations } & \multirow[b]{2}{*}{ 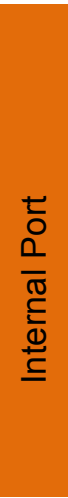 } & \multicolumn{5}{|c|}{$\begin{array}{l}\text { Stakeholders poised to } \\
\text { implement }\end{array}$} & \multirow[b]{2}{*}{ 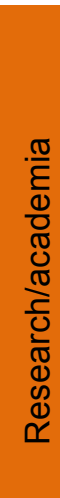 } \\
\hline & & 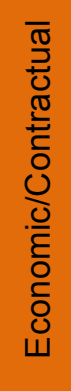 & 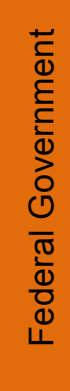 & 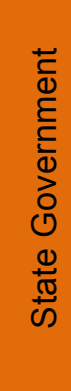 & 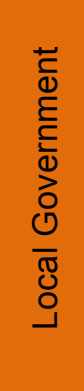 & 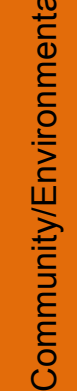 & \\
\hline $\begin{array}{l}\text { Adjust coastal agency's enabling legislation to allow for } \\
\text { more proactive regulation of facilities }\end{array}$ & & & & $X$ & & & \\
\hline $\begin{array}{l}\text { Assure that fill in not used as structural support in potential } \\
\text { V zones }\end{array}$ & & & & $\mathrm{X}$ & & & \\
\hline $\begin{array}{l}\text { Change state building standards and freeboard } \\
\text { requirements }\end{array}$ & & & & $X$ & $\mathrm{X}$ & & \\
\hline Condition permitting on debris cleanup standards & & & & $\mathrm{X}$ & & & \\
\hline $\begin{array}{l}\text { Create fitness of purpose regulations to ensure piers and } \\
\text { docks are adequately protected }\end{array}$ & & & & $X$ & & & \\
\hline $\begin{array}{l}\text { Create new coastal } A \text {-zone policies for structures subject } \\
\text { to wave activity currently designated as } V \text {-zone }\end{array}$ & & & & $\mathrm{X}$ & & & \\
\hline Create performance measures & & & & $X$ & $\mathrm{X}$ & & \\
\hline Create post-event rebuilding requirements & & & & $X$ & $x$ & & \\
\hline $\begin{array}{l}\text { Create tighter controls for development of infrastructure } \\
\text { and commercial facilities in floodplains }\end{array}$ & & & $\mathrm{X}$ & $\mathrm{X}$ & $\mathrm{X}$ & & \\
\hline $\begin{array}{l}\text { Incorporate provisions into design and permitting of water- } \\
\text { based projects to address preparedness, response and } \\
\text { recovery of hazards related to hurricanes and SLR }\end{array}$ & & & & $X$ & $\mathrm{X}$ & & \\
\hline Total & 0 & 0 & 1 & 10 & 5 & 0 & 0 \\
\hline
\end{tabular}


Table 13 - Table of Long Range Planning Strategies

\begin{tabular}{|c|c|c|c|c|c|c|c|}
\hline \multirow[b]{2}{*}{ Long range planning efforts } & \multirow[b]{2}{*}{ 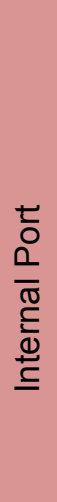 } & \multicolumn{5}{|c|}{$\begin{array}{l}\text { Stakeholders poised to } \\
\text { implement }\end{array}$} & \multirow[b]{2}{*}{ 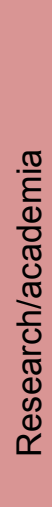 } \\
\hline & & 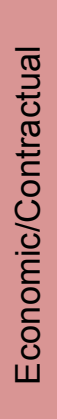 & 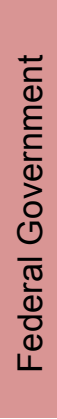 & 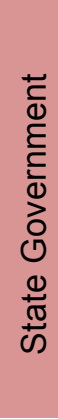 & 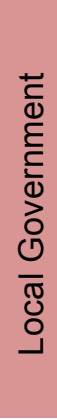 & 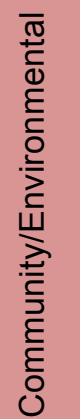 & \\
\hline Create new state sea level rise policies & & & & $\mathrm{X}$ & & & \\
\hline Create regional-scale hazard mitigation plans & & & $X$ & $X$ & & & \\
\hline Incorporate hazard mitigation into transportation plan & & & & $\mathrm{X}$ & $X$ & & \\
\hline Create regional climate adaptation plans & & & $X$ & $X$ & & & \\
\hline $\begin{array}{l}\text { Require local comprehensive plans to consider } \\
\text { hazard resilience }\end{array}$ & & & & $\mathrm{X}$ & $\mathrm{X}$ & $\mathrm{X}$ & \\
\hline Streamline post-hurricane permitting process & & & & $X$ & & & \\
\hline Total & 0 & 0 & 2 & 6 & 2 & 1 & 0 \\
\hline
\end{tabular}


Table 14 - Table of Construction and Design Strategies

\begin{tabular}{|c|c|c|c|c|c|c|c|}
\hline \multirow[b]{2}{*}{ Construction and design } & \multicolumn{7}{|c|}{ Stakeholders poised to implement } \\
\hline & 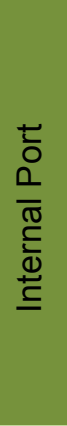 & 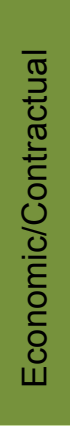 & 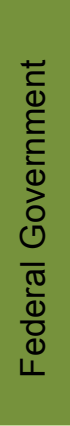 & 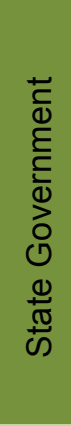 & 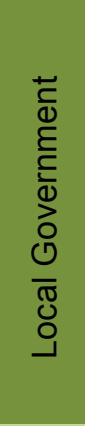 & 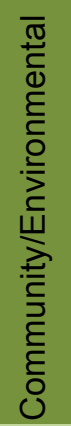 & 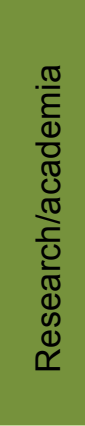 \\
\hline \multicolumn{8}{|l|}{ Construct or modify features off port lands } \\
\hline Build breakwater & & & $\mathrm{X}$ & $\mathrm{X}$ & & & \\
\hline Build flood barriers or dike & & & $X$ & $X$ & $\mathrm{X}$ & & \\
\hline Create offsite evacuation safe haven & $\mathrm{X}$ & & & & $x$ & & \\
\hline Create seasonal facilities & $\mathrm{X}$ & & & & & & \\
\hline Create single rail line to inland hub & $X$ & & & $\mathrm{X}$ & & & \\
\hline Design bridges with sacrificial sections & & & & $x$ & & & \\
\hline $\begin{array}{l}\text { Design connecting infrastructure to aid in } \\
\text { evacuation of port }\end{array}$ & & & & $X$ & $\mathrm{X}$ & & \\
\hline Elevate connecting infrastructure & & & & $\mathrm{X}$ & & & \\
\hline Move the port & $\mathrm{X}$ & & & $\mathrm{X}$ & $X$ & & \\
\hline Restore barrier islands that protect the port & & & $\mathrm{X}$ & $\mathrm{X}$ & & $X$ & \\
\hline $\begin{array}{l}\text { Restore wetlands that serve to block and slow } \\
\text { hurricane winds }\end{array}$ & & & $\mathrm{X}$ & $\mathrm{X}$ & & $X$ & \\
\hline Tunnel connecting roads beneath flood plain & & & & $\mathrm{X}$ & & & \\
\hline Subtotal & 4 & 0 & 4 & 10 & 4 & 2 & 0 \\
\hline \multicolumn{8}{|l|}{ Construct or modify features on port lands } \\
\hline Install breakaway walls & $\mathrm{X}$ & & & & & & \\
\hline Build with sacrificial decking materials & $X$ & & & & & & \\
\hline Build with steel and concrete & $x$ & & & & & & \\
\hline Construct barriers around individual structures & $x$ & & & & & & \\
\hline Design and build submersible structures & $x$ & & & & & & \\
\hline Design debris catchment fencing system & $\mathrm{X}$ & & & & & & \\
\hline Elevate existing structures & $\mathrm{X}$ & & & & & & \\
\hline Elevate footprint of port & $\mathrm{X}$ & & & & & & \\
\hline Harden structures & $\mathrm{X}$ & & & & & & \\
\hline Install anchors for hurricane tie down straps & $\mathrm{X}$ & & & & & & \\
\hline Install pass-through fencing & $\mathrm{X}$ & & & & & & \\
\hline $\begin{array}{l}\text { Retrofit the Port facility to protect against flood } \\
\text { damage }\end{array}$ & $x$ & & & & & & \\
\hline Subtotal & 12 & 0 & 0 & 0 & 0 & 0 & 0 \\
\hline Total & 16 & 0 & 4 & 10 & 4 & 2 & 0 \\
\hline
\end{tabular}


Table 15 - Table of Private Sector and Insurance Policies

\begin{tabular}{llll}
\multicolumn{1}{c}{ Private sector and insurance policies } & & Stakeholders poised to \\
\multicolumn{1}{c|}{} & & &
\end{tabular}


Table 16 - Table of Emergency Preparation, Response, and Recovery Strategies

\begin{tabular}{|c|c|c|c|c|c|c|c|}
\hline \multirow[b]{2}{*}{ Emergency preparation, response, and recovery } & \multicolumn{7}{|c|}{$\begin{array}{l}\text { Stakeholders poised to } \\
\text { implement }\end{array}$} \\
\hline & 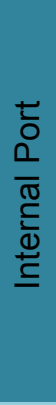 & 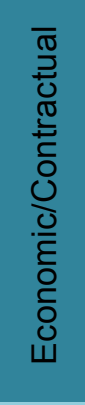 & 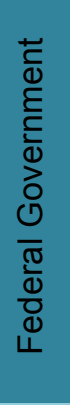 & 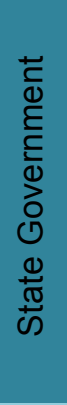 & 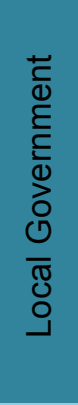 & 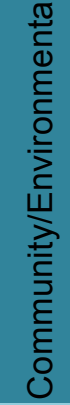 & 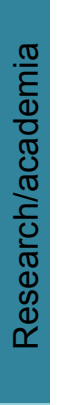 \\
\hline Business continuity plans & 3 & 3 & 0 & 1 & 1 & 0 & 0 \\
\hline Create business continuity plans & $\mathrm{X}$ & $\mathrm{X}$ & & & & & \\
\hline Create data storage and offsite data backup plan & $\mathrm{X}$ & $\mathrm{X}$ & & & & & \\
\hline $\begin{array}{l}\text { Create pre-storm master agreements with service } \\
\text { providers to facilitate timely cleanup }\end{array}$ & $X$ & $\mathrm{X}$ & & $X$ & $X$ & & \\
\hline Subtotal & 3 & 3 & 0 & 1 & 1 & 0 & 0 \\
\hline Drills and pre-event training & 3 & 3 & 2 & 3 & 3 & 0 & 2 \\
\hline Conduct emergency drills and trainings & $\mathrm{X}$ & $\mathrm{X}$ & $\mathrm{X}$ & $\mathrm{X}$ & $X$ & & \\
\hline Conduct site assistance visits to identify problem areas & & $\mathrm{X}$ & & $\mathrm{x}$ & $\mathrm{X}$ & & $\mathrm{x}$ \\
\hline $\begin{array}{l}\text { Conduct table top scenario exercises that involve multiple } \\
\text { actors and agencies }\end{array}$ & $X$ & & $\mathrm{X}$ & $\mathrm{X}$ & $\mathrm{X}$ & & $x$ \\
\hline Manage port inventory pre-storm to reduce stocks & $\mathrm{X}$ & $\mathrm{X}$ & & & & & \\
\hline Subtotal & 3 & 3 & 2 & 3 & 3 & 0 & 2 \\
\hline Post-storm actions & 2 & 1 & 1 & 1 & 1 & 0 & 0 \\
\hline Address employee needs & $\mathrm{X}$ & $\mathrm{X}$ & & & & & \\
\hline Utilize port as emergency response asset & $\mathrm{X}$ & & $\mathrm{X}$ & $\mathrm{X}$ & $\mathrm{X}$ & & \\
\hline Subtotal & 2 & 1 & 1 & 1 & 1 & 0 & 0 \\
\hline Response and recovery guidance & 8 & 6 & 3 & 8 & 9 & 0 & 3 \\
\hline Create debris removal plan and management task force & & & & $\mathrm{X}$ & $\mathrm{X}$ & & \\
\hline Create emergency communications plans & $\mathrm{X}$ & $\mathrm{X}$ & & & $\mathrm{X}$ & & \\
\hline Create evacuation plan and procedures & $\mathrm{x}$ & $\mathrm{X}$ & & & & & \\
\hline Create facility-level hurricane plan & $\mathrm{X}$ & $\mathrm{X}$ & & & & & \\
\hline Create guidance for evacuation of shore side facilities & & & & $\mathrm{X}$ & $\mathrm{X}$ & & $\mathrm{X}$ \\
\hline $\begin{array}{l}\text { Create guidance for use of infrastructure for facility } \\
\text { evacuation, import of supplies, emergency transport in the } \\
\text { case of a hazard scenario }\end{array}$ & & & & $\mathrm{X}$ & $X$ & & $\mathrm{X}$ \\
\hline $\begin{array}{l}\text { Create guidance to address spills, contaminations caused } \\
\text { by inundation, and facility closures }\end{array}$ & & & & $X$ & $\mathrm{X}$ & & $\mathrm{X}$ \\
\hline Create hazard mitigation plans & $\mathrm{x}$ & $\mathrm{X}$ & & $\mathrm{X}$ & $\mathrm{X}$ & & \\
\hline Create list of essential navigational aids & & & $\mathrm{X}$ & & & & \\
\hline Develop emergency response plans & $\mathrm{X}$ & $\mathrm{x}$ & & $\mathrm{X}$ & $\mathrm{X}$ & & \\
\hline Post-storm employee management plan & $\mathrm{X}$ & $X$ & & & & & \\
\hline Utilize emergency siren warning system & $\mathrm{X}$ & & $\mathrm{X}$ & $\mathrm{X}$ & $\mathrm{X}$ & & \\
\hline Utilize multi-agency response planning & $\mathrm{X}$ & & $\mathrm{X}$ & $\mathrm{X}$ & $X$ & & \\
\hline Subtotal & 8 & 6 & 3 & 8 & 9 & $\mathbf{0}$ & 3 \\
\hline Storm preparations & 10 & 10 & 1 & 0 & 0 & 0 & 0 \\
\hline Evacuate the port & $\mathrm{X}$ & $\mathrm{X}$ & & & & & \\
\hline $\begin{array}{l}\text { Manage items on location that could potentially end up as } \\
\text { debris }\end{array}$ & $\mathrm{X}$ & $x$ & & & & & \\
\hline
\end{tabular}


Secure port equipment in place

Block and reinforce dry-docked vessels

Cover equipment

Move equipment to high ground on port property

Press up petroleum tanks with water

Shut off power at port

Tie equipment and containers down using lash-in-place methods

Use storm-resilient equipment

Shut down the waterways

Subtotal

Total $x \quad x$

$X \quad X$

$X \quad X$

$x \quad x$

$X \quad X$

$X \quad X$

$\mathrm{X} X$

$\mathrm{X} X$

$x$

$\begin{array}{lllllll}10 & 10 & 1 & 0 & 0 & 0 & 0\end{array}$ 
Table 17 - Table of Research Strategies

\begin{tabular}{|c|c|c|c|c|c|c|c|}
\hline \multirow[b]{2}{*}{ Research Strategies } & \multicolumn{7}{|c|}{$\begin{array}{l}\text { Stakeholders poised to } \\
\text { implement }\end{array}$} \\
\hline & 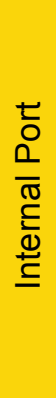 & 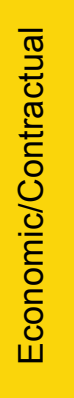 & 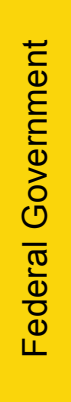 & 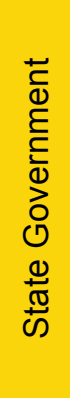 & 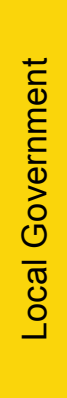 & 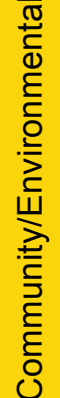 & 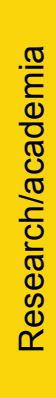 \\
\hline Conduct damage assessments & $\mathrm{X}$ & $\mathrm{X}$ & $\mathrm{X}$ & $\mathrm{X}$ & $\mathrm{X}$ & & $\mathrm{X}$ \\
\hline Conduct risk and vulnerability assessment & $x$ & $x$ & $\mathrm{x}$ & $\mathrm{x}$ & $\mathrm{X}$ & & $\mathrm{x}$ \\
\hline Create coastal flood study & & & $\mathrm{X}$ & $x$ & $\mathrm{X}$ & & $\mathrm{X}$ \\
\hline $\begin{array}{l}\text { Develop a build-out analysis for the entire coastal flood } \\
\text { plain within the region }\end{array}$ & & & & $\mathrm{X}$ & $x$ & & $\mathrm{x}$ \\
\hline $\begin{array}{l}\text { Evaluate impact of increasing storm surge heights and } \\
\text { SLR on facilities }\end{array}$ & $\mathrm{X}$ & & $\mathrm{X}$ & $\mathrm{X}$ & $X$ & & $\mathrm{X}$ \\
\hline Identify funding streams to support adaptation & $\mathrm{x}$ & $x$ & $\mathrm{X}$ & $x$ & $\mathrm{X}$ & $\mathrm{X}$ & $\mathrm{X}$ \\
\hline Improve hurricane forecasting accuracy & & & $\mathrm{X}$ & & & & $\mathrm{X}$ \\
\hline Incentivize resilience strategies (FEMA) & & & $\mathrm{X}$ & & & & \\
\hline $\begin{array}{l}\text { Inventory hazardous material and debris and create } \\
\text { debris removal plan }\end{array}$ & $x$ & $\mathrm{X}$ & & $\mathrm{X}$ & $X$ & & \\
\hline $\begin{array}{l}\text { Perform study of port to identify upgrades necessary to } \\
\text { limit damage due to flooding }\end{array}$ & $x$ & & & $\mathrm{X}$ & $\mathrm{X}$ & & $\mathrm{X}$ \\
\hline Re-map flood-prone areas to account for sea level rise & & & $\mathrm{X}$ & $\mathrm{x}$ & $X$ & & $\mathrm{X}$ \\
\hline $\begin{array}{l}\text { Develop and utilize gaming exercises, simulations, and } \\
\text { scenario planning tools }\end{array}$ & $x$ & $\mathrm{x}$ & $\mathrm{X}$ & $\mathrm{X}$ & $X$ & $\mathrm{X}$ & $\mathrm{X}$ \\
\hline Utilize academic and NGO research expertise & $\mathrm{x}$ & $\mathrm{X}$ & $\mathrm{X}$ & $\mathrm{X}$ & $\mathrm{X}$ & $\mathrm{X}$ & $\mathrm{X}$ \\
\hline Total & 8 & 6 & 10 & 11 & 11 & 3 & 11 \\
\hline
\end{tabular}


Table 18 - Table of Networks and New Ways of Thinking Strategies

\begin{tabular}{|c|c|c|c|c|c|c|c|}
\hline \multirow[b]{2}{*}{ Networks and new ways of thinking } & \multirow[b]{2}{*}{ 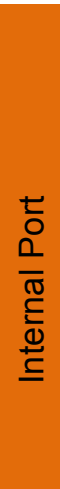 } & \multicolumn{5}{|c|}{$\begin{array}{c}\text { Stakeholders poised to } \\
\text { implement }\end{array}$} & \multirow[b]{2}{*}{ 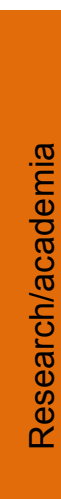 } \\
\hline & & 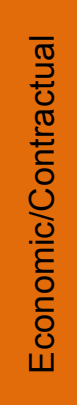 & 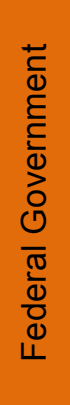 & 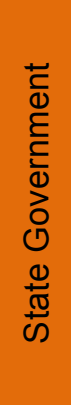 & 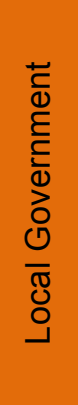 & 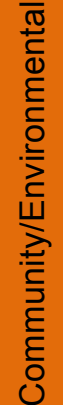 & \\
\hline \multicolumn{8}{|l|}{ Collaboration } \\
\hline Collaborate between agencies & & & $\mathrm{X}$ & $\mathrm{X}$ & $\mathrm{X}$ & & $\mathrm{X}$ \\
\hline Collaborate to develop emergency plans & $\mathrm{X}$ & $\mathrm{x}$ & $X$ & $X$ & $X$ & & \\
\hline Convene council of experts to develop resilience plans & $x$ & & & $x$ & $x$ & $\mathrm{x}$ & $x$ \\
\hline $\begin{array}{l}\text { Establish a climate change adaptation local partnership } \\
\text { to coordinate environmental networks }\end{array}$ & $\mathrm{X}$ & & & $\mathrm{X}$ & $\mathrm{X}$ & $\mathrm{x}$ & \\
\hline Form climate change commission & & & & $X$ & $\mathrm{X}$ & $\mathrm{X}$ & \\
\hline Improve stakeholder coordination & $\mathrm{X}$ & & $\mathrm{X}$ & $\mathrm{X}$ & $\mathrm{X}$ & $\mathrm{x}$ & $\mathrm{x}$ \\
\hline Create regional climate monitoring offices & & & $X$ & & & & \\
\hline Subtotal & 4 & 1 & 4 & 6 & 6 & 4 & 3 \\
\hline \multicolumn{8}{|l|}{ Empower government } \\
\hline $\begin{array}{l}\text { Enable FEMA to prioritize mitigation activities through } \\
\text { Code of Federal Regulations }\end{array}$ & & & $X$ & & & & \\
\hline Enhance community rating system (NFIP) & & & $\mathrm{X}$ & & & & \\
\hline Follow FEMA disaster mitigation philosophy & & & $\mathrm{X}$ & & & & \\
\hline $\begin{array}{l}\text { Incorporate storm preparedness into DHS voluntary } \\
\text { inspection program }\end{array}$ & & & $\mathrm{X}$ & & & & \\
\hline $\begin{array}{l}\text { Require enhanced insurance coverage as federal } \\
\text { funding stipulations }\end{array}$ & & & $X$ & & & & \\
\hline Hire more staff for hurricane events & $\mathrm{X}$ & $\mathrm{X}$ & & $\mathrm{X}$ & $\mathrm{X}$ & & \\
\hline Subtotal & 1 & 1 & 5 & 1 & 1 & 0 & 0 \\
\hline \multicolumn{8}{|l|}{ Improve information flow } \\
\hline $\begin{array}{l}\text { Develop an ongoing outreach program for coastal } \\
\text { developers engineers, and others on best ways to } \\
\text { safeguard lives and property }\end{array}$ & & & & $\mathrm{X}$ & $\mathrm{X}$ & $\mathrm{x}$ & \\
\hline Educate stakeholders about risks and strategies & $\mathrm{X}$ & & $X$ & $x$ & $\mathrm{X}$ & $\mathrm{x}$ & $x$ \\
\hline $\begin{array}{l}\text { Join international networks related to port climate } \\
\text { change adaptation }\end{array}$ & $\mathrm{X}$ & & & $\mathrm{X}$ & $\mathrm{X}$ & $\mathrm{X}$ & \\
\hline Share information & $\mathrm{x}$ & $\mathrm{x}$ & $\mathrm{x}$ & $\mathrm{x}$ & $\mathrm{x}$ & $\mathrm{X}$ & $\mathrm{x}$ \\
\hline Subtotal & 3 & 1 & 2 & 4 & 4 & 4 & 2 \\
\hline \multicolumn{8}{|l|}{ Increase planning horizons } \\
\hline Better incorporate port into Statewide hazard plans & & & & $\mathrm{X}$ & & & \\
\hline $\begin{array}{l}\text { Create new multi-tiered action plan for the port (restore, } \\
\text { enhance, anticipate the future) }\end{array}$ & $x$ & & & & & & \\
\hline Improve land-use planning for resilience & & & & $\mathrm{X}$ & $\mathrm{X}$ & & \\
\hline Improve long-range planning & $\mathrm{x}$ & $\mathrm{x}$ & $\mathrm{x}$ & $\mathrm{x}$ & $X$ & & $\mathrm{x}$ \\
\hline Incorporate resilience as a part of the Statewide plan & & & & $\mathrm{x}$ & & & \\
\hline Preplan for post-storm rebuilding & & & $\mathrm{X}$ & $\mathrm{x}$ & $\mathrm{x}$ & & \\
\hline Subtotal & 2 & 1 & 2 & 5 & 3 & 0 & 1 \\
\hline
\end{tabular}


Be more proactive on resilience

Consider port as bigger piece of state infrastructure

Consider resilience as economic advantage

Emphasize role of port in disaster recovery

Learn from past events

Plan for incremental adaptation

Practice no-regrets strategies

Think long term

Use resilience as a marketing strategy

Subtotal

Total

$\begin{array}{ccccccc}X & X & X & X & X & X & \\ & & & X & & & \\ X & X & & X & X & & \\ X & & X & X & X & X & \\ X & X & X & X & X & X & x \\ X & X & X & X & X & X & \\ X & X & X & X & X & & \\ X & X & X & X & X & X & X \\ X & X & & & X & & \\ \mathbf{8} & \mathbf{7} & \mathbf{6} & \mathbf{8} & \mathbf{8} & \mathbf{5} & \mathbf{2} \\ 18 & 11 & 19 & 24 & 22 & 13 & 8\end{array}$

STAKEHOLDER GROUPS BEST POISED TO IMPLEMENT STRATEGIES
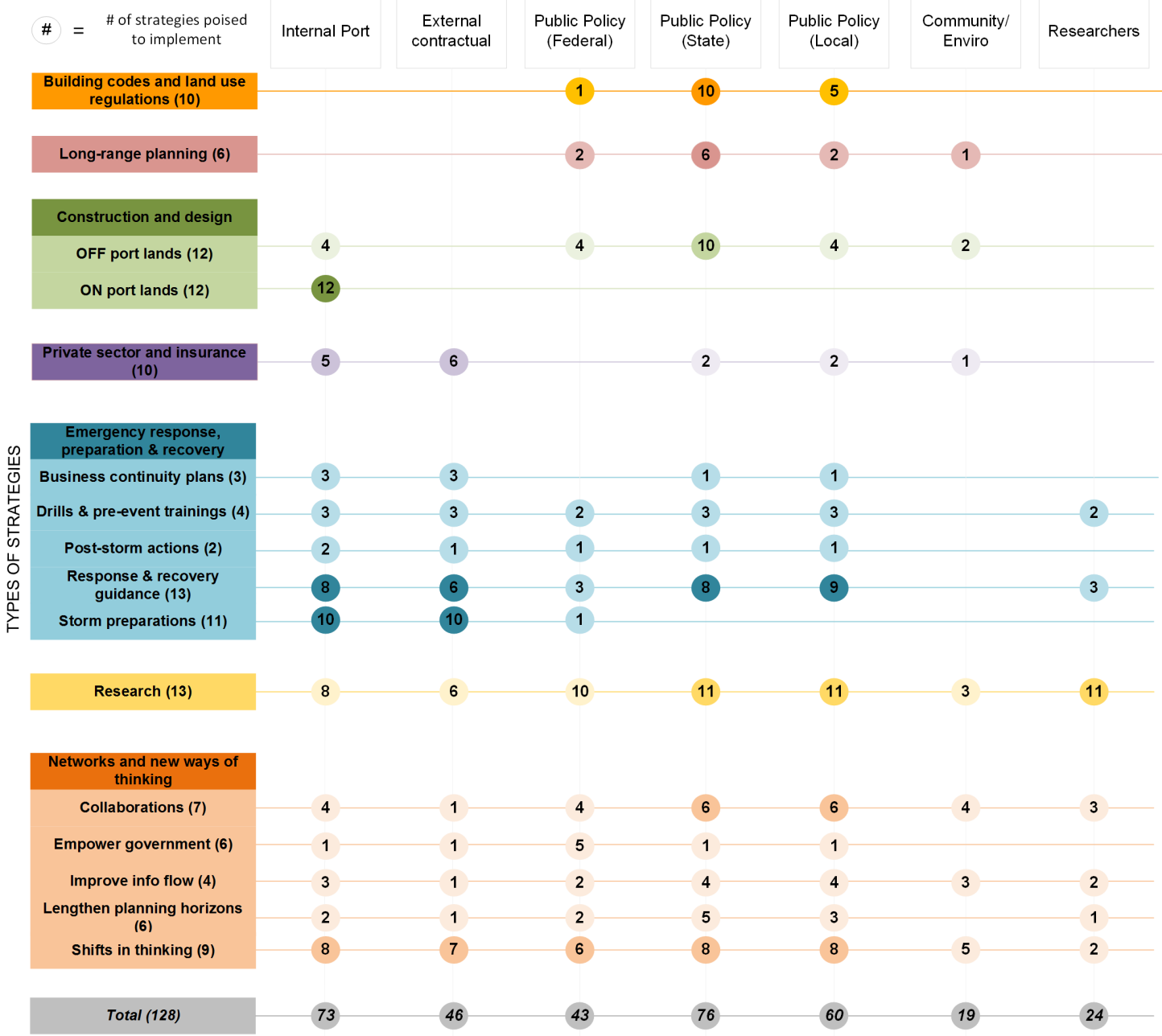

Figure 8 -- Stakeholder groups poised for leadership (Version 1) 


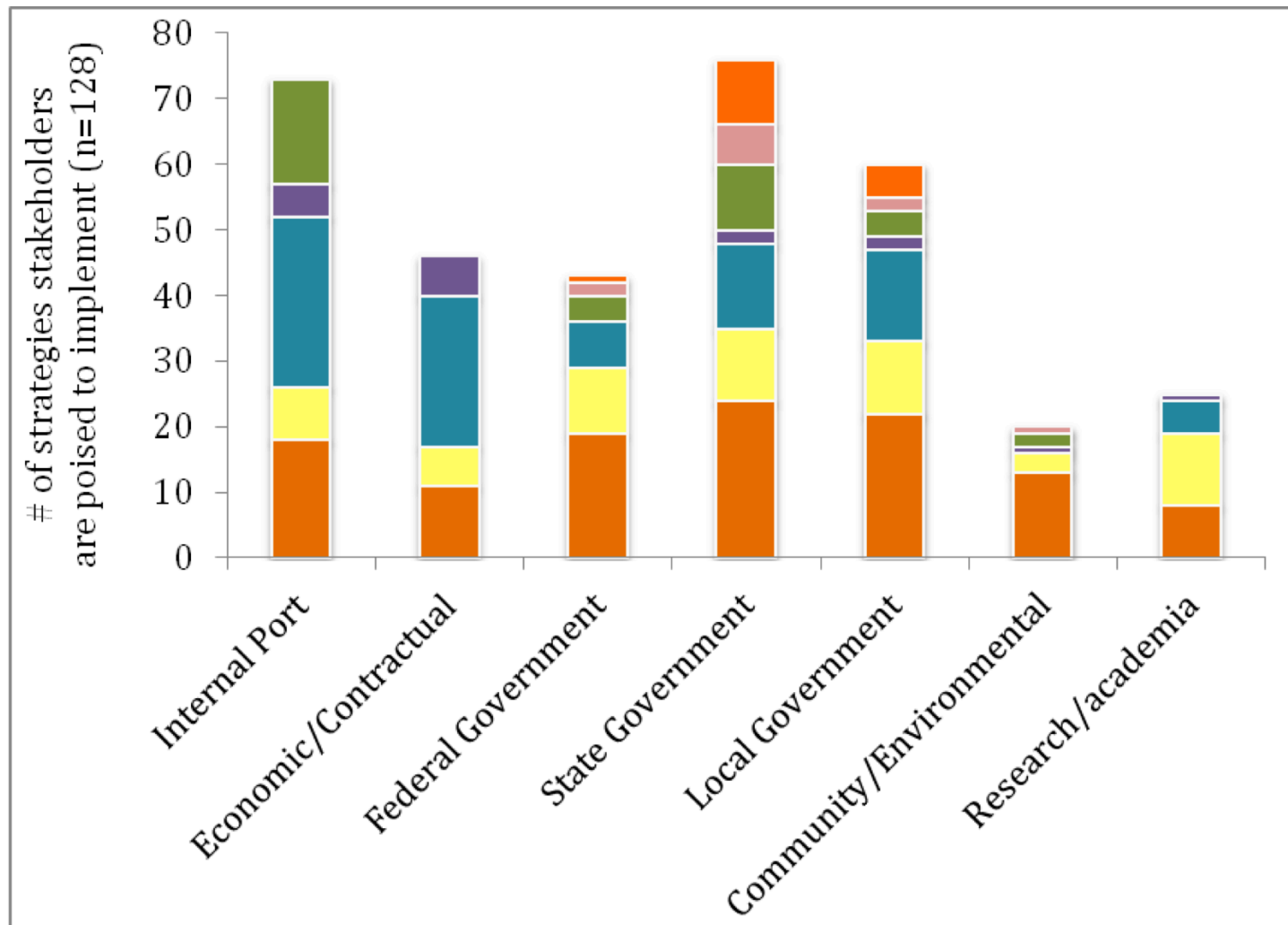

@ Building codes and land use regulations

- Long range planning efforts

$\square$ Constructions and design

- Private sector and insurance policies

Emergency preparation, response, and recovery

Research (inc. risk assessment, forecasting improvements, and projections) $\square$ Networks and new ways of thinking

Figure 9 -- Stakeholders poised for leadership (Version 2) 


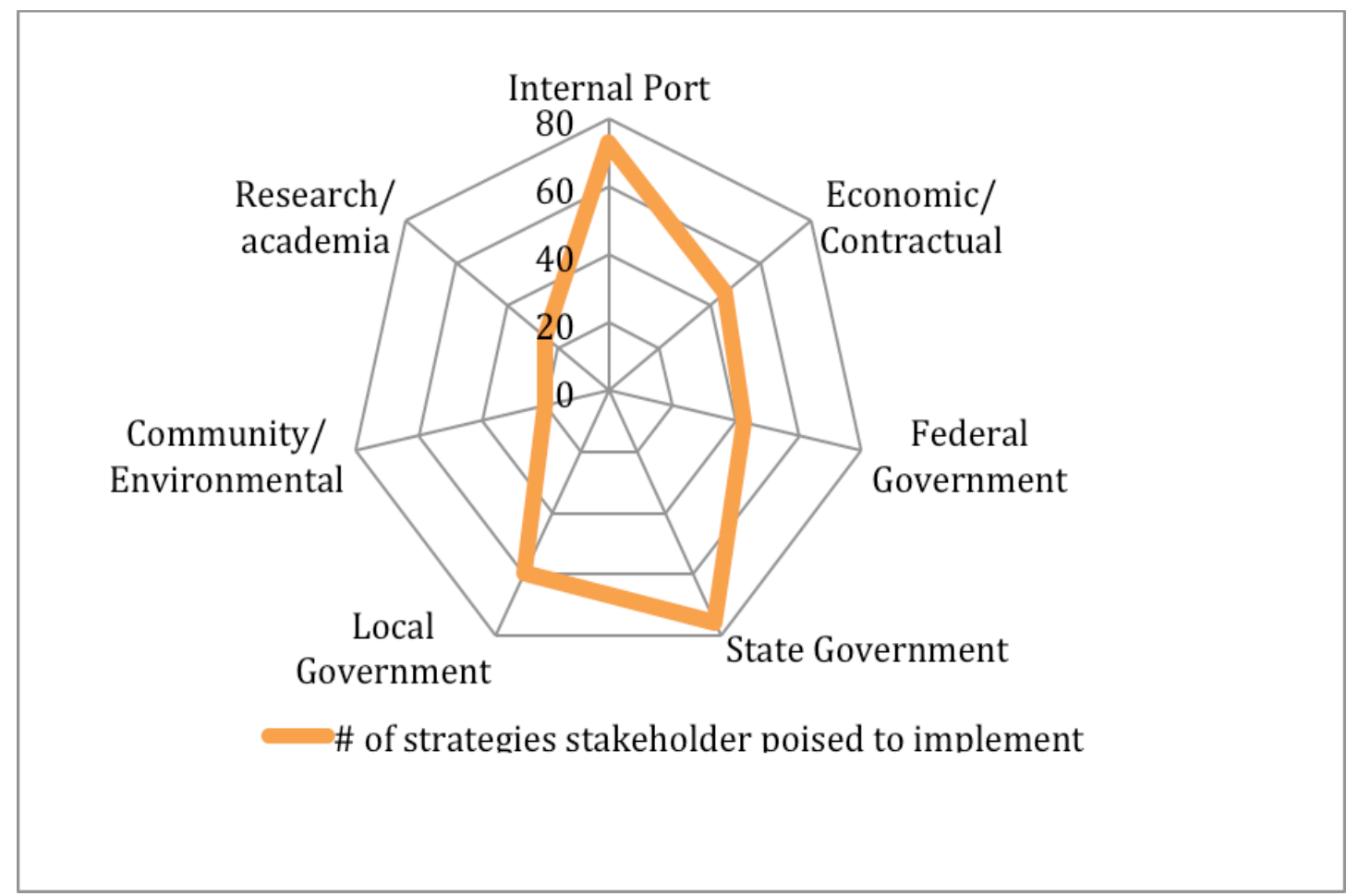

Figure 10 -- Summary of stakeholders and strategies 


\section{SUPPLEMENTAL MATERIALS}

Table 19 -- Documents reviewed from Gulfport

\begin{tabular}{|c|c|c|c|c|c|c|}
\hline & $\underline{\text { Title }}$ & Author & $\begin{array}{l}\text { Sponsor } \\
\text { organization }\end{array}$ & $\underline{\text { Sector }}$ & dype of & $\underline{\text { Year }}$ \\
\hline 1 & Gulfport Master Plan Update 2007 Final Report & $\begin{array}{l}\text { BDMJM Harris } \\
\text { and AECOM } \\
\end{array}$ & MSPA & Port and private & Master Plan & 2007 \\
\hline 2 & $\begin{array}{l}\text { The Impact of Hurricane Katrina on Mississippi's } \\
\text { Commercial Public Ports and Opportunities for } \\
\text { Expansion of the Ports }\end{array}$ & PEER & $\begin{array}{l}\text { Mississippi } \\
\text { Legislature }\end{array}$ & $\begin{array}{l}\text { Public (local, state, } \\
\text { regional) }\end{array}$ & Report & 2006 \\
\hline 3 & Hurricane Katrina Damage Assessment Report & MSPA & MSPA & Port and private & $\begin{array}{c}\text { Damage } \\
\text { assessment }\end{array}$ & 2005 \\
\hline 4 & Port of Gulfport Restoration Program Action Plan & MSPA & MSPA & Port and private & Master Plan & 2008 \\
\hline 5 & $\begin{array}{l}\text { Master Planning the Port of Gulfport, Mississippi - } \\
\text { Rebirth after Katrina }\end{array}$ & John Webb & MSPA & Port and private & Report & 2007 \\
\hline 6 & $\begin{array}{l}\text { Hurricanes Katrina and Rita - Implications for } \\
\text { Hurricane Science and Engineering }\end{array}$ & $\begin{array}{l}\text { Building and Fire } \\
\text { Research } \\
\text { Laboratory NIST }\end{array}$ & $\begin{array}{l}\text { National Science } \\
\text { Board }\end{array}$ & Public (federal) & Report & 2006 \\
\hline 7 & \begin{tabular}{|l|} 
Environmental Environmental Assessment and \\
Environmental Review Record for Community \\
Development Block Grant Disaster Recovery Project at \\
State Port at Gulfport
\end{tabular} & MSPA & MDA & Port and private & $\begin{array}{l}\text { Environmental } \\
\text { Assessment }\end{array}$ & 2010 \\
\hline 8 & Hurricane Katrina Storm Surge Reconnaissance & Fritz et al & Georgia Tech & $\begin{array}{l}\text { Academia and non- } \\
\text { profit }\end{array}$ & $\begin{array}{c}\text { Academic } \\
\text { paper }\end{array}$ & 2008 \\
\hline 9 & $\begin{array}{l}\text { Read the Port of Gulfport's Restoration Program } \\
\text { Description }\end{array}$ & MSPA & MSPA & Port and private & Press Release & 2008 \\
\hline 10 & Sustainable Restoration of the Port of Gulfport & Reilly Morse & $\begin{array}{l}\text { Mississippi } \\
\text { Center for Justice }\end{array}$ & $\begin{array}{l}\text { Academia and non- } \\
\text { profit }\end{array}$ & Report & 2011 \\
\hline 11 & $\begin{array}{l}\text { The Plan for the Implementation of the Port of Gulfport } \\
\text { Restoration Program }\end{array}$ & CH2M Hill & MSPA & Port and private & Master Plan & 2010 \\
\hline 12 & Advancing in the Aftermath IV: & Loren C. Scott & Capital One N.A. & $\begin{array}{c}\text { Academia and non- } \\
\text { profit }\end{array}$ & Report & 2007 \\
\hline 13 & Letter of opposition to HUD funding & Multiple & STEPS & $\begin{array}{l}\text { Academia and non- } \\
\text { profit }\end{array}$ & $\begin{array}{c}\text { Letter of } \\
\text { opposition } \\
\end{array}$ & 2007 \\
\hline 14 & Maritime Severe Weather Contingency Port Plan & USCG & USCG & Public (federal) & $\begin{array}{c}\text { Hazard } \\
\text { mitigation plan } \\
\end{array}$ & 2010 \\
\hline 15 & Central Harrison County Connector Highway & MDOT & MDOT & $\begin{array}{l}\text { Public (local, state, } \\
\text { regional) }\end{array}$ & FAQ & 2007 \\
\hline 16 & Testimony of Governor Haley Barbour & Haley Barbour & \begin{tabular}{|l|} 
Ad Hoc \\
Subcommittee on \\
Disaster \\
Recovery \\
\end{tabular} & $\begin{array}{l}\text { Public (local, state, } \\
\text { regional) }\end{array}$ & Testimony & 2009 \\
\hline 17 & $\begin{array}{l}\text { Port of Gulfport Restoration Program Presubmittal } \\
\text { Meeting }\end{array}$ & CH2M Hill & MSPA & Port and private & Presentation & 2009 \\
\hline 18 & State of Mississippi Hazard Mitigation Plan & State of MS & MEMA & $\begin{array}{c}\begin{array}{c}\text { Public (local, state, } \\
\text { regional) }\end{array} \\
\end{array}$ & $\begin{array}{c}\text { Hazard } \\
\text { mitigation plan } \\
\end{array}$ & 2007 \\
\hline \multicolumn{7}{|c|}{ DOCUMENTS NOT ANALYZED } \\
\hline 19 & Federal Disaster Recovery Grant Report & MDA & MDA & Port and private & Grant report & 2011 \\
\hline 20 & $\begin{array}{l}\text { Gulfport Restoration Program Action Plan - } \\
\text { Amendment } 5 \text { - Modification } 1\end{array}$ & MSPA & MSPA & Port and private & $\begin{array}{l}\text { Port planning } \\
\text { document }\end{array}$ & 2008 \\
\hline 21 & MSPA Current and Projected Jobs & MSPA & MSPA & Port and private & Report & 2011 \\
\hline 22 & Question received on "request for ideas" proposal & MSPA & MSPA & Port and private & $\begin{array}{l}\text { Response to } \\
\text { public } \\
\text { comment }\end{array}$ & 2010 \\
\hline 23 & $\begin{array}{l}\text { The Projected Economic Impacts from Container } \\
\text { Terminal Development at Gulfport }\end{array}$ & TranSystems & MSPA & Port and private & $\begin{array}{c}\text { Economic } \\
\text { assessment }\end{array}$ & 2011 \\
\hline 24 & $\begin{array}{l}\text { Mississippi Unified Long-Range Transportation } \\
\text { Infrastructure Plan }\end{array}$ & MDOT & MDOT & $\begin{array}{c}\begin{array}{c}\text { Public (local, state, } \\
\text { regional) }\end{array} \\
\end{array}$ & Transport Plan & 2007 \\
\hline 25 & State of Mississippi Budget 2011 & \begin{tabular}{|l|} 
Joint Legislative \\
Budget \\
Committee \\
\end{tabular} & \begin{tabular}{|l|} 
Joint Legislative \\
Budget \\
Committee \\
\end{tabular} & $\begin{array}{l}\text { Public (local, state, } \\
\text { regional) }\end{array}$ & Budget & 2011 \\
\hline 26 & Mississippi Pay Now, Pay Later: & $\begin{array}{l}\text { American } \\
\text { Security Project }\end{array}$ & $\begin{array}{l}\text { American } \\
\text { Security Project }\end{array}$ & $\begin{array}{l}\text { Academia and non- } \\
\text { profit }\end{array}$ & Pamphlet & 2011 \\
\hline 27 & $\begin{array}{l}\text { Hurricane Katrina: Profile of a Super Cat Lessons and } \\
\text { Implications for Catastrophe Risk Management }\end{array}$ & $\begin{array}{l}\text { Risk Management } \\
\text { Solutions }\end{array}$ & $\begin{array}{l}\text { Risk Management } \\
\text { Solutions }\end{array}$ & Port and private & Report & 2005 \\
\hline 28 & Harrison County Flood Insurance Study & FEMA & FEMA & Public (federal) & $\begin{array}{c}\text { Flood } \\
\text { insurance } \\
\text { study }\end{array}$ & 2009 \\
\hline 29 & \begin{tabular}{|l|} 
Mississippi Coastal Analysis Project - Coastal \\
Documentation and Main Engineering Report
\end{tabular} & FEMA & FEMA & Public (federal) & Report & 2008 \\
\hline 30 & $\begin{array}{l}\text { Mississippi Coastal Improvements Project, Interim } \\
\text { Report }\end{array}$ & USACE & USACE & Public (federal) & Report & 2006 \\
\hline 31 & City of Gulfport Budget 2011 & City of Gulfport & City of Gulfport & $\begin{array}{l}\text { Public (local, state, } \\
\text { regional) }\end{array}$ & Budget & 2011 \\
\hline 32 & Harrison County Hurricane Surge Map & FEMA & FEMA & Public (federal) & $\begin{array}{l}\text { Flood } \\
\text { insurance } \\
\text { study }\end{array}$ & 2009 \\
\hline
\end{tabular}

background indicates document analyzed and coded) 
Table 20 -- Documents reviewed in Providence

\begin{tabular}{|c|c|c|c|c|c|c|}
\hline & Title & Author & $\begin{array}{l}\text { Sponsor } \\
\text { organization }\end{array}$ & Sector & 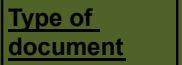 & Year \\
\hline & DOCUMENTS ANALYZED & & & & & \\
\hline 1 & $\begin{array}{l}\text { Natural Hazards: Hurricanes, Floods, and Sea } \\
\text { Level Rise in theMetro Bay Region Special Area } \\
\text { Management Plan }\end{array}$ & Pam Rubinoff & Ri CRMC & $\begin{array}{l}\text { Public (local, } \\
\text { state, regional) }\end{array}$ & Policy & 2009 \\
\hline 2 & $\begin{array}{l}\text { Strategy for Reducing Risks from Natural Hazards } \\
\text { in Providence, Rhode Island: A Multi-Hazard } \\
\text { Mitigation Plan }\end{array}$ & $\begin{array}{l}\text { City of Providence } \\
\text { Local Hazard } \\
\text { Mitigation } \\
\text { Committee, Maguire } \\
\text { Group, Inc. }\end{array}$ & $\begin{array}{l}\text { Rhode Island } \\
\text { Emergency } \\
\text { Management } \\
\text { Agency }\end{array}$ & $\begin{array}{l}\text { Public (local, } \\
\text { state, regional) }\end{array}$ & $\begin{array}{l}\text { Hazard } \\
\text { mitigation plan }\end{array}$ & 2011 \\
\hline 3 & $\begin{array}{l}\text { Bays, Rivers, and Watersheds Systems-Level Plan: } \\
2009-1013\end{array}$ & Ames Colt & $\begin{array}{l}\text { Rhode Island } \\
\text { Bays, Rivers, } \\
\text { and Watersheds } \\
\text { Coordination } \\
\text { Team }\end{array}$ & $\begin{array}{l}\text { Public (local, } \\
\text { state, regional) }\end{array}$ & $\begin{array}{l}\text { State planning } \\
\text { document }\end{array}$ & 2008 \\
\hline 4 & $\begin{array}{l}\text { Promet Marine Services Hurricane Preparedness } \\
\text { Checklist }\end{array}$ & $\begin{array}{l}\text { Promet Marine } \\
\text { Services }\end{array}$ & $\begin{array}{l}\text { Promet Marine } \\
\text { Services }\end{array}$ & Port and private & $\begin{array}{l}\text { Hazard } \\
\text { mitigation plan }\end{array}$ & 2011 \\
\hline 5 & Hazard Identification and Risk Assessment & $\begin{array}{l}\text { Providence } \\
\text { Emergency } \\
\text { Management } \\
\text { Agency }\end{array}$ & $\begin{array}{l}\text { Providence } \\
\text { Emergency } \\
\text { Management } \\
\text { Agency }\end{array}$ & $\begin{array}{l}\text { Public (local, } \\
\text { state, regional) }\end{array}$ & Report & 2010 \\
\hline 6 & Rhode Island State Hazard Mitigation Plan & $\begin{array}{l}\text { Rhode Island } \\
\text { Emergency } \\
\text { Management } \\
\text { Agency } \\
\end{array}$ & $\begin{array}{l}\text { Rhode Island } \\
\text { Emergency } \\
\text { Management } \\
\text { Agency } \\
\end{array}$ & $\begin{array}{l}\text { Public (local, } \\
\text { state, regional) }\end{array}$ & $\begin{array}{l}\text { Hazard } \\
\text { mitigation plan }\end{array}$ & 2009 \\
\hline & DOCUMENTS NOT ANALYZED & & & & & \\
\hline 7 & $\begin{array}{l}\text { Beyond No Regrets: Assessing the Economic } \\
\text { Efficiency of Climate Adaptation in Rhode Island }\end{array}$ & Kyle A. Polar & $\begin{array}{l}\text { Brown } \\
\text { University }\end{array}$ & $\begin{array}{l}\text { Academia and } \\
\text { non-profit }\end{array}$ & Student Report & 2010 \\
\hline 8 & $\begin{array}{l}\text { Summary: Preliminary Assessment of Rhode } \\
\text { Island's Vulnerability to Climate Change and its } \\
\text { Options for Adaptation Action }\end{array}$ & $\begin{array}{l}\text { Timmons Roberts et } \\
\text { al }\end{array}$ & $\begin{array}{l}\text { Brown } \\
\text { University }\end{array}$ & $\begin{array}{l}\text { Academia and } \\
\text { non-profit }\end{array}$ & Report & 2010 \\
\hline 9 & Economic Effects of Allens Avenue Businesses & FXM Associates & $\begin{array}{l}\text { Providence } \\
\text { Working } \\
\text { Waterfront } \\
\text { Alliance }\end{array}$ & Port and private & $\begin{array}{l}\text { Economic } \\
\text { assessment }\end{array}$ & 2008 \\
\hline 10 & National Infrastructure Protection Plan & Unassigned & $\begin{array}{l}\text { Dept. of } \\
\text { Homeland } \\
\text { Security }\end{array}$ & Public (federal) & $\begin{array}{l}\text { Planning } \\
\text { document }\end{array}$ & 2009 \\
\hline 11 & $\begin{array}{l}\text { Rhode Island and Southeastern Massachusetts } \\
\text { Area Contingency Plan }\end{array}$ & \begin{tabular}{|l|} 
Rhode Island and \\
Southeastern \\
Massachusetts Area \\
Committee \\
\end{tabular} & USCG & Public (federal) & $\begin{array}{l}\text { Hazard } \\
\text { mitigation plan }\end{array}$ & 2010 \\
\hline 12 & $\begin{array}{l}\text { Rhode Island Hurricane Evacuation Study } \\
\text { Technical Report }\end{array}$ & USACE & USACE & Public (federal) & Report & 1995 \\
\hline 13 & FY07 Economic Monitoring Report & $\begin{array}{l}\text { Ri Economic } \\
\text { Monitoring } \\
\text { Collaborative }\end{array}$ & $\begin{array}{l}\text { Ri Bays, Rivers } \\
\text { and Watersheds } \\
\text { Coordination } \\
\text { Team }\end{array}$ & $\begin{array}{l}\text { Public (local, } \\
\text { state, regional) }\end{array}$ & Report & 2007 \\
\hline 14 & $\begin{array}{l}\text { Rhode Island's Ports and Commercial Harbors: A } \\
\text { GIS Inventory of Current Uses and Infrastructure }\end{array}$ & Jennifer McCann & $\begin{array}{l}\text { Rhode Island } \\
\text { Statewide } \\
\text { Planning }\end{array}$ & $\begin{array}{l}\text { Public (local, } \\
\text { state, regional) }\end{array}$ & Report & 2011 \\
\hline 15 & Rhode Island Pay Now Pay Later & $\begin{array}{l}\text { American Security } \\
\text { Project }\end{array}$ & $\begin{array}{l}\text { American } \\
\text { Security Project }\end{array}$ & $\begin{array}{l}\text { Academia and } \\
\text { non-profit }\end{array}$ & Pamphlet & 2011 \\
\hline 16 & $\begin{array}{l}\text { Natural Hazards and Flood Plain Management in } \\
\text { Upper Narragansett Bay }\end{array}$ & $\begin{array}{l}\text { Malcolm Spaulding, } \\
\text { James Hu, } \\
\text { Christopher Baxter }\end{array}$ & $\begin{array}{l}\text { University of } \\
\text { Rhode Island }\end{array}$ & $\begin{array}{l}\text { Academia and } \\
\text { non-profit }\end{array}$ & Student Report & 2007 \\
\hline
\end{tabular}

(Green

background indicates document was analyzed and coded) 


\section{REFERENCES}

Becker, A, M Acciaro, R Asariotis, E Carera, L Cretegny, P Crist, M Esteban, A Mather, S Messner, S Naruse, AKY Ng, S Rahmstorf, M Savonis, D Song, V Stenek, and AF Velegrakis. 2013. "A Note on Climate change adaptation for seaports: A challenge for global ports, a challenge for global society." Climatic Change 120 (4):683-695. doi: 10.1007/s10584-013-0843-z.

Becker, A, S Inoue, M Fischer, and B Schwegler. 2012. "Climate change impacts on international seaports: knowledge, perceptions, and planning efforts among port administrators." Climatic Change 110 (1-2):5-29. doi: 10.1007/s10584-011-0043-7.

Becker, A, P Matson, M Fischer, and M Mastrandrea. 2014. "Towards seaport resilience for climate change adaptation: Stakeholder perceptions of hurricane impacts in Gulfport (MS) and Providence (RI)." Progress in Planning. doi: 10.1016/j.progress.2013.11.002.

Bender, MA, TR Knutson, RE Tuleya, JJ Sirutis, GA Vecchi, ST Garner, and IM Held. 2010. "Modeled impact of anthropogenic warming on the frequency of intense Atlantic hurricanes." Science 327 (5964):454-8. doi: 10.1126/science.1180568.

Bidwell, D, T Dietz, and D Scavia. 2013. "Fostering knowledge networks for climate adaptation." Nature Climate Change 3 (7):610-611.

Bryson, JM. 2004. "What to do when stakeholders matter: stakeholder identification and analysis techniques." Public management review 6 (1):21-53.

Burroughs, R. 2005. "Institutional change in the Port of New York." Maritime Policy \& Management 32 (3):315-328. doi: 10.1080/03088830500139919.

Cash, DW, and SC Moser. 2000. "Linking global and local scales: designing dynamic assessment and management processes." Global environmental change 10 (2):109-120.

Charmaz, K. 2003. "Qualitative interviewing and grounded theory analysis." Inside interviewing: New lenses, new concerns:311-330.

Cheong, SM. 2011. "Policy solutions in the US." Climatic Change 106 (1):57-70.

Cone, J, S Rowe, J Borberg, E Stancioff, B Doore, and K Grant. 2013. "Reframing Engagement Methods for Climate Change Adaptation." Coastal Management 41 (4):345-360. doi: 10.1080/08920753.2013.803926.

CRC (Rhode Island Coastal Resources Center). 2014. "Coastal Resources Center: Capacity Building." Accessed 8/16/2014. http://www.crc.uri.edu/initiatives page/capacitybuilding/.

CRMC (Rhode Island Coastal Resources Management Council). 2011. Natural Hazards: Hurricanes, Floods, and Sea Level Rise in theMetro Bay Region Special AreaManagement Plan.

CRMC (Rhode Island Coastal Resources Management Council). 2009. Climate Change Policy, Working Draft.

Curtis, SA. 2007. Hurricane Katrina Damage Assessment: Louisiana, Alabama, and Mississippi Ports and Coasts. Reston, Virginia: American Society of Civil Engineers.

De Langen, PW. 2004. The Performance of Seaport Clusters; A Framework to Analyze Cluster Performance and an Application to the Seaport Clusters of Durban, Rotterdam and the Lower Mississippi: Erasmus University Rotterdam.

Dooms, M, and A Verbeke. 2006. "An integrative framework for long-term strategic seaport 
planning: An application to the port of Antwerp." Ports are More Than Piers. De Lloyd: Antwerp:173-192.

Eakin, H, and AL Luers. 2006. "Assessing the Vulnerability of Social-Environmental Systems." Annual Review of Environment and Resources 31 (1):365-394. doi:

10.1146/annurev.energy.30.050504.144352.

EPA (United States Environmental Protection Agency). 2008. Planning for Climate Change Impacts at U.S. Ports. White Paper prepared by ICF International for the USEPA.

FEMA (Federal Emergency Management Agency). 2013. National Disaster Recovery Framework. Washington, DC.

Few, R, K Brown, and EL Tompkins. 2007. "Public participation and climate change adaptation: Avoiding the illusion of inclusion." Climate Policy 7 (1):46-59. doi: 10.1080/14693062.2007.9685637.

Flyvbjerg, B. 2006. "Five misunderstandings about case-study research." Qualitative inquiry 12 (2):219-245.

Freeman, RE. 1984. Strategic management: A stakeholder approach. Cambridge, UK: Cambridge University Press.

Glaser, B, and A Strauss. 1967. The discovery of grounded theory: Strategies for qualitative research. Chicago, IL: Aldine.

Goss, R. 1990. "Economic policies and seaports: The economic functions of seaports." Maritime Policy \& Management 17 (3):207-219.

Grinsted, A, JC Moore, and S Jevrejeva. 2013. "Projected Atlantic hurricane surge threat from rising temperatures." Proceedings of the National Academy of Sciences. doi: 10.1073/pnas.1209980110.

Haezendonck, E. 2001. Essays on strategy analysis for seaports: Garant Uitgevers NV.

Hall, P, and W Jacobs. 2007. "Ports in proximity, proximity in ports: towards a typology." Proceedings of International Congress of Ports.

Hall, PV, and W Jacobs. 2010. "Shifting proximities: The maritime ports sector in an era of global supply chains." Regional Studies 44 (9):1103-1115.

Hallegatte, S, C Green, RJ Nicholls, and J Corfee-Morlot. 2013. "Future flood losses in major coastal cities." Nature Climate Change 3 (9):802-806. doi: 10.1038/nclimate1979.

Horton, BP, S Rahmstorf, SE Engelhart, and AC Kemp. 2014. "Expert assessment of sea-level rise by AD 2100 and AD 2300." Quaternary Science Reviews 84:1-6.

IPCC (Intergovernmental Panel on Climate Change). 2012. Managing the risks of extreme events and disasters to advance climate change adaptation. Special report of the Intergovernmental Panel on Climate Change. In SREX, edited by C.B. Field, V. Barros, T.F. Stocker, D. Qin, D.J. Dokken, K.L. Ebi, M.D. Mastrandrea, K.J. Mach, G.-K. Plattner, S.K. Allen, M. Tignor and P.M. Midgley. Cambridge, UK, and New York, NY, USA.

Kates, R, W Clark, R Corell, J Hall, C Jaeger, I Lowe, J McCarthy, H Schellnhuber, B Bolin, and N Dickson. 2001. "Sustainable Science." Science 641 (642):292.

Kates, RW, WR Travis, and TJ Wilbanks. 2012. "Transformational adaptation when incremental adaptations to climate change are insufficient." Proceedings of the National Academy of Sciences 109 (19):7156-7161.

Lei, Y, Ja Wang, Y Yue, H Zhou, and W Yin. 2013. "Rethinking the relationships of vulnerability, resilience, and adaptation from a disaster risk perspective." Natural Hazards 70 (1):609-627. doi: 10.1007/s11069-013-0831-7. 
Memos, C. 2004. "Port Planning." In Port engineering: planning, construction, maintenance, and security. John Wiley \& Sons.

Morse, R. 2011. Sustainable Restoration of the Port of Gulfport. Edited by Mississippi Center for Justice. Jackson, MS.

Moser, S, and J Ekstrom. 2010. "A framework to diagnose barriers to climate change adaptation." Proceedings of the National Academy of Sciences 107 (51):22026.

Moser, SC. 2010. "Now more than ever: The need for more societally relevant research on vulnerability and adaptation to climate change." Applied Geography 30 (4):464-474. doi: 10.1016/j.apgeog.2009.09.003.

Moser, SC, and MT Boykoff. 2013. Successful Adaptation to Climate Change: Linking Science and Policy in a Rapidly Changing World: Routledge.

MSPG (Mississippi State Port at Gulfport). 2012. "Port Commission Nixes 25' Elevation Plan." Accessed 11/07/2012. http://www.portofthefuture.com/News.aspx?NewsID=301.

NCA (National Climate Assessment Report). 2014. Climate Change Impacts in the United States: The Third National Climate Assessment. edited by J Melillo, Terese Richmond and Gary Yohe. U.S. Goverment Printing Office, Washington, DC: United States Global Research Program.

$\mathrm{Ng}$, AKY, A Becker, and M Fischer. 2013. "A theoretical discussion on climate

change, port adaptation strategies and institutions. ." Proceedings of the Canadian Transportation Research Forum, Halifax, NS, Canada, June 10-12.

NRC (National Research Council). 2010. America's Climate Choices: Adapting to the Impacts of Climate Change. Edited by T.J. Wilbanks, D.K. Jacobs, B. Baughman, G. Benjamin, D.J.L. Buizer, F.S. Chapin, D.W.P. Cherry, B. Davis, D.S. Emori and K.L. Ebi, America's Climate Choices. Washington, DC.

NRC (National Research Council). 2013. Abrupt Impacts of Climate Change: Anticipating Surprises: The National Academies Press.

Poumadère, M, C Mays, G Pfeifle, and AT Vafeidis. 2008. "Worst case scenario as stakeholder decision support: a 5-to 6-m sea level rise in the Rhone delta, France." Climatic Change $91(1-2): 123-143$.

Ratcliff, DE. 1994. "Analytic induction as a qualitative research method of analysis." Accessed May 13. http://finntrack.co.uk/shift/analytic.pdf.

RICCC (Rhode Island Climate Change Commission). 2012. "Adapting to Climate Change in the Ocean State: A Starting Point." Accessed July 1.

http://www.rilin.state.ri.us/Reports/Climate Change Commission Prog Report Final 1115 12 final 2.pdf.

Shackley, S, and R Deanwood. 2002. "Stakeholder perceptions of climate change impacts at the regional scale: implications for the effectiveness of regional and local responses." Journal of Environmental Planning and Management 45 (3):381-402.

Stocker, DQ. 2013. "Climate change 2013: The physical science basis." Working Group I Contribution to the Fifth Assessment Report of the Intergovernmental Panel on Climate Change, Summary for Policymakers, IPCC.

Tompkins, E, R Few, and K Brown. 2008. "Scenario-based stakeholder engagement: Incorporating stakeholders preferences into coastal planning for climate change." Journal of environmental management 88 (4):1580-1592.

Travis, WR. 2009. "Going to extremes: propositions on the social response to severe climate change." Climatic Change 98 (1-2):1-19. doi: 10.1007/s10584-009-9661-8. 
USDOT (United States Department of Transportation). 2013. "Impacts of Climate Change and Variability on Transportation Systems and Infrastructure: The Gulf Coast Study, Phase 2 -- Screening for Vulnerability."

Van Kleef, E, LJ Frewer, GM Chryssochoidis, JR Houghton, S Korzen-Bohr, T Krystallis, J Lassen, U Pfenning, and G Rowe. 2006. "Perceptions of food risk management among key stakeholders: Results from a cross-European study." Appetite 47 (1):46-63.

Walker, B, D Salt, and W Reid. 2006. Resilience thinking: sustaining ecosystems and people in a changing world. Washington, DC: Island Press.

Ward, D. 2001. "Stakeholder involvement in transport planning: participation and power." Impact Assessment and Project Appraisal 19 (2):119-130.

Wilbanks, TJ, and RW Kates. 1999. "Global change in local places: how scale matters." Climatic Change 43 (3):601-628.

Winkelmans, WaN, T.,. 2007. "Port master planning: Balancing stakeholders' interests." In The reality and dilemmas of globalization. Gdansk: The Foundation of the Development of Gdansk University, edited by K. Dobrowolski, Zurek, J. 